Journal: Marine Geology

https://doi.org/10.1016/j.margeo.2021.106539

\title{
The erosive power of the Malvinas Current: Influence of bottom currents on morpho-sedimentary features along the northern Argentine margin (SW Atlantic Ocean)
}

\author{
Henriette Wilckens ${ }^{a, b *}$, Elda Miramontes ${ }^{a, b}$, Tilmann Schwenk ${ }^{a}$, Camila Artana ${ }^{c}$, Wenyan \\ Zhang $^{d}$, Alberto R. Piola ${ }^{e, f}$, Michele Baques ${ }^{e, g}$, Christine Provost ${ }^{h}$, F. Javier Hernández- \\ Molina ${ }^{\prime}$, Meret Felgendreher ${ }^{j}$, Volkhard Spieß ${ }^{a}$, Sabine Kasten ${ }^{a, b, k}$ \\ a Faculty of Geosciences, University of Bremen, Bremen, Germany \\ b MARUM - Center for Marine Environmental Sciences, University of Bremen, Germany \\ c MERCATOR-OCÉAN, Parc Technologique du Canal, Ramonville Saint Agne, France \\ ${ }^{d}$ Institute of Coastal Systems, Helmholtz-Zentrum Hereon, Geesthacht, Germany \\ e Departamento Oceanografía, Servicio de Hidrografía Naval, Buenos Aires, Argentina \\ ${ }^{f}$ Instituto Franco-Argentino para el Estudio del Clima y sus Impactos (UMI-IFAECI/CNRS-CONICET-UBA), \\ Buenos Aires, Argentina \\ g Acoustic Propagation Department, Argentinian Navy Research Office and UNIDEF (National Council of \\ Scientific and Technical Research - Ministry of Defense), Buenos Aires, Argentina \\ h Laboratoire LOCEAN-IPSL, Sorbonne Universités (UPMC, Univ. Paris 6) CNRS-IRD-MNHN, Paris, France \\ i Department of Earth Sciences, Royal Holloway University of London, Egham, Surrey, UK \\ i Institute of Geosciences, Kiel University, Kiel, Germany \\ ${ }^{k}$ Alfred Wegener Institute Helmholtz Centre for Polar and Marine Research, Bremerhaven, Germany \\ * Corresponding author: Henriette Wilckens: cwilcken@uni-bremen.de
}

\section{Abstract:}

Sediment deposits formed mainly under the influence of bottom currents (contourites) are widely used as high-resolution archives for reconstructing past ocean conditions. However, the driving processes of Contourite Depositional Systems (CDS) are not entirely understood. The aim of this study is to establish a clearer link between contourite features and the oceanographic processes that form them. The morphosedimentary characteristics of a large CDS were analysed together with the current dynamics along the northern Argentine continental margin. This study combines multibeam bathymetry, seismo-acoustic data, sediment samples, vessel-mounted Acoustic Doppler Current Profiler (VM-ADCP) data and numerical modelling of ocean currents.

The contouritic features include large contourite terraces (La Plata Terrace, Ewing Terrace) and an abraded surface connecting the terraces, as well as smaller erosional and depositional features like moats, erosion surfaces on the Ewing Terrace, sediment waves and contourite 
drifts. Measured and modelled near-bottom currents are vigorous (up to $63 \mathrm{~cm} / \mathrm{s}$ at $150-200$ $\mathrm{m}$ above the seafloor) where abraded surfaces and moats are present, and relatively weak (below $30 \mathrm{~cm} / \mathrm{s}$ ) on the La Plata Terrace and the Ewing Terrace. Generally, bottom currents follow the upper and middle slope morphology. Decreasing velocity of water masses flowing northward leads to less erosion and finer sediment deposits. ADCP data and the hydrodynamic model show the formation of eddies near the seafloor which probably lead to the small erosion surfaces on the Ewing Terrace, even though it is mainly a depositional environment. Overall, this study contributes to a better understanding of the formation of CDS and can help future reconstructions of past ocean conditions based on sedimentary structures.

Keywords: Contour current; Deep-water environment; Sediment drift; Contourite Depositional Systems; Sediment transport, Argentine Margin

\section{Introduction}

Continental margins can be shaped by ocean currents, which influence sediment erosion and deposition even at large scales (Heezen, 1959; Heezen and Hollister, 1964; Stow et al., 2009). Sediment deposits formed mainly under the influence of bottom currents (i.e. currents related to oceanographic processes flowing near the seafloor) are classified as contourites (Rebesco and Camerlenghi, 2008; Rebesco et al., 2014). These currents often supply oxygen and nutrients favouring the development of deep-sea ecosystems with high biodiversity, for instance cold-water corals are often found in contourite depositional systems (Hebbeln et al., 2016; Steinmann et al., 2020). Bottom currents that lead to large sediment deposits can also control the distribution of microplastics and lead to hotspots in the same area where biodiversity is high, which is a potential threat for marine ecosystems (Kane et al., 2020). Furthermore, contourites are important for several fields including paleoclimatology and palaeoceanography, risk management regarding slope instabilities and hydrocarbon exploration (Rebesco et al., 2014; Hernández-Molina et al., 2018; Miramontes et al., 2018). Many physical oceanographic processes, ranging from quasi-steady geostrophic currents, 
sub-inertial oscillations, tides to internal waves, have potentially significant impact on the morphogenesis and evolution of contourites. On a long time scale, the development of contourites is subject to climate-induced change in thermohaline circulation and isostatic movements (e.g. tectonics). However, it is still not clear how these multi-scale processes interact and control the formation and evolution of contourites. Understanding the present deposition mechanisms is necessary for the reconstruction of past ocean conditions based on the geological record (Surlyk and Lykke-Andersen, 2007; Preu et al., 2012; Betzler et al., 2013).

A large Contourite Depositional System (CDS) has been recognised along the northern Argentine and Uruguayan margin (Hernández-Molina et al., 2009, Hernández-Molina et al., 2016a; Preu et al., 2012, Preu et al., 2013). The CDS includes three large contourite terraces that have been documented along the continental margin off the Río de la Plata Estuary (northern Argentina) in close proximity to the Mar del Plata (MdP) submarine Canyon (Preu et al., 2012, Preu et al., 2013). The study area is located in the confluence zone of the northward flowing Malvinas Current and the southward flowing Brazil Current (Fig. 1; Artana et al., 2019; Piola and Matano, 2019). This complex oceanographic setting makes it an interesting study area for analysing the influence of currents on contourite formation. In this study we use a multidisciplinary approach based on multibeam bathymetry, hydroacoustic data, sediment samples, vessel-mounted Acoustic Doppler Current Profiler (VM-ADCP) data, Conductivity, Temperature and Depth (CTD) data and 25 years of high-resolution ocean reanalysis. The main aim of the study is to derive further insights into basic physical oceanographic mechanisms that control the formation of large-scale contourites in such a complex and unique oceanographic configuration. More specifically, this multidisciplinary study has the following three main goals: 1) to report on the characteristics of near-bottom currents in the BrazilMalvinas Confluence Zone; 2) to discuss differences within the contourite system regarding seafloor morphology, sediment architecture and grain size; 3) to interpret and discuss the oceanographic processes that may contribute to the formation of the observed contouritic features. 

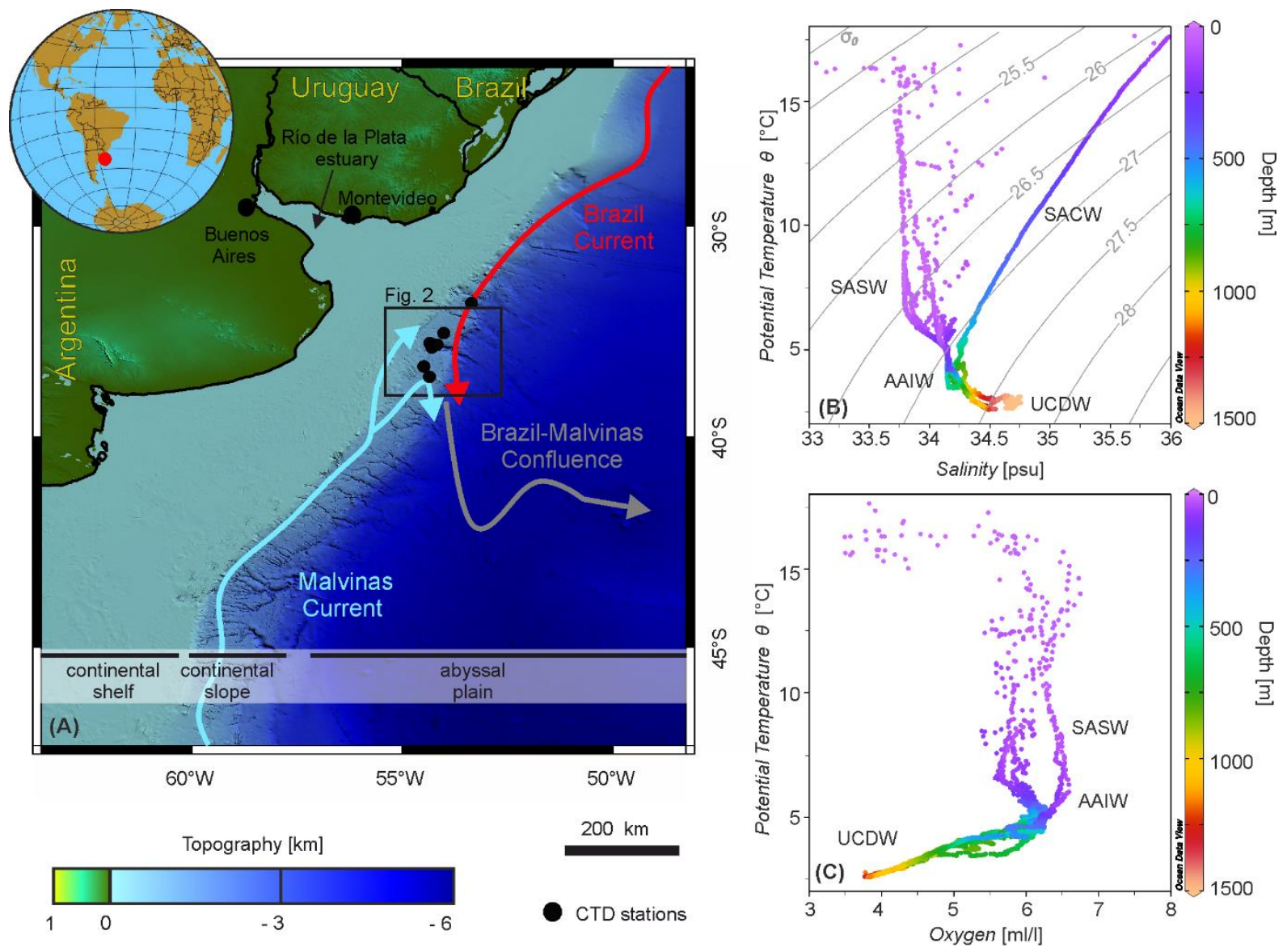

Fig. 1. (A) Regional bathymetric map showing the SE American margin. The arrows indicate the general circulation pattern of the cold Malvinas Current, the warm Brazil Current and their confluence. $(B / C)$ Potential temperature versus Salinity/Oxygen based on CTD data collected during Cruise SO260 that allowed the identification of different water masses: SASW: Subantarctic Surface Water, SACW: South Atlantic Central Water, AAIW: Antarctic Intermediate Water, UCDW: Upper Circumpolar Deep Water. $\sigma 0$ : potential density anomaly.

\section{Regional setting}

\subsection{Oceanographic framework}

Strong ocean currents are present along the Argentine and Uruguayan continental margin from the surface down to $2000 \mathrm{~m}$ water depth (Piola and Matano, 2019). The Malvinas Current (MC) transports cold and nutrient rich waters northwards. The Brazil Current flows southwards along the continental slope and is shallower than the Malvinas Current (Piola and Matano, 2019). The study area is located in the region where these two boundary currents encounter, forming the Brazil-Malvinas Confluence Zone. On average, the axis of the confluence zone is situated at an approximate latitude of $38^{\circ} \mathrm{S}$ (Gordon and Greengrove, 1986; Artana et al., 
2019; Piola and Matano, 2019). The confluence shows large migrations at synoptic (800 km) and interannual $(300 \mathrm{~km})$ scales compared to rather small seasonal changes $(<150 \mathrm{~km})$ (Artana et al., 2019, Artana et al., 2021a). Numerical simulations suggest that at the confluence the Malvinas Current splits into two branches (Provost et al., 1995; Artana et al., 2019). The offshore branch joins the Brazil Current and detaches from the continental slope while the inner branch subducts and continues flowing northward along the upper continental slope (Provost et al., 1995; Artana et al., 2019). Currents flowing on the wide Argentine shelf continue flowing northward beyond the Brazil-Malvinas Confluence (Piola et al., 2018).

The Malvinas and the Brazil Current both carry several different water masses which are defined by their different thermohaline, nutrient and dissolved oxygen characteristics (Maamaatuaiahutapu et al., 1994). The northward flowing water masses at the continental slope from sea surface to bottom are: Subantarctic Surface Water (SASW), Antarctic Intermediate Water (AAIW), Circumpolar Deep Water (CDW) and the Antarctic Bottom Water (AABW) (Preu et al., 2013; Piola and Matano, 2019). The southward flowing water masses are: Tropical Water, South Atlantic Central Water (SACW), AAIW and North Atlantic Deep Water (NADW) (Preu et al., 2013; Valla et al., 2018; Piola and Matano, 2019). Southward flowing AAIW is an older (saltier and less oxygenated) variety of the AAIW recirculated around the South Atlantic subtropical gyre (Valla et al., 2018). The NADW flows southward between Upper Circumpolar Deep Water (UCDW) and Lower Circumpolar Deep Water (LCDW) (Reid et al., 1977; Piola and Matano, 2019). The depth of the interfaces between the water masses varies with time and between locations. In close proximity to the MdP Canyon the interfaces between AAIW, UCDW, NADW, LCDW and AABW are located at 1200, 2000, 3200, 3800 m, respectively (Preu et al., 2013). The zone of interest in this study (located at 450-1400 m water depth) is mainly under the influence of the AAIW (identified by a salinity minimum and a dissolved oxygen maximum) and the UCDW (identified by a dissolved oxygen minimum) (Fig. 1B and C, Preu et al., 2013). The interface between the AAIW and the UCDW is characterised by an increase of salinity and dissolved oxygen decrease with depth (Fig. 1B and C). This modern ocean circulation and stratification pattern was established during the 
Middle Miocene after the onset of the (paleo-) NADW circulation in the southern hemisphere, which significantly influenced the formation of the CDS (Preu et al., 2012).

\subsection{Geological setting}

The study area is located at the passive volcanic-rifted northern Argentine continental margin, offshore the Río de la Plata estuary formed during the Cretaceous period (Fig. 1A; Hinz et al., 1999; Franke et al., 2007). The rivers flowing into the Río de la Plata, together with the Colorado and Negro rivers, that are located further south, are the main sources of sediments to the continental margin (Giberto et al., 2004; Voigt et al., 2013; Razik et al., 2015a; Franco-Fraguas et al., 2016). Frenz et al. (2003a) and Razik et al. (2015a) analysed the sediment grain size of surface sediments from the SE South American margin and suggested that sedimentation and grain size distribution on the Argentine and Uruguayan margin are strongly controlled by the oceanic circulation. The continental slope is composed of contourites, forming a large Contourite Depositional System (CDS) composed of moats/channels, contouritic terraces, abraded surfaces and sediment drift deposits (Urien and Ewing, 1974; Hernández-Molina et al., 2009, Hernández-Molina et al., 2016a; Krastel et al., 2011; Preu et al., 2012, Preu et al., 2013; Voigt et al., 2016; Warratz et al., 2017, Warratz et al., 2019). At the southern Argentine margin four terraces (i.e. relatively flat surfaces) are present: Nágera Terrace at $\sim 500 \mathrm{~m}$ depth, the Perito Moreno Terrace at $\sim 1000 \mathrm{~m}$ depth, the Piedra Buena Terrace at $\sim 2500 \mathrm{~m}$ depth and the Valentin Feilberg Terrace at $\sim 3500 \mathrm{~m}$ depth (Hernández-Molina et al., 2009). The Nágera Terrace, the Perito Moreno and the Valentin Feilberg Terrace can be followed further to the north but in the northern part of the margin they are known as La Plata Terrace at $~ 500 \mathrm{~m}$ depth, the Ewing Terrace at $\sim 1200 \mathrm{~m}$ depth and the Necochea Terrace at $~ 3500$ m depth (Urien and Ewing, 1974; Preu et al., 2013). Seismic data shows that the La Plata Terrace is much wider south of the MdP Canyon compared to the north (Preu et al., 2013). The La Plata Terrace is deeper ( 500 m) south of the MdP Canyon compared to the north where it is located at shallower depth ( 400 m) (Preu et al., 2013). Contourite terraces can show depositional and erosional features and often correspond to the 
landward upper part of plastered drifts (Hernández-Molina et al., 2016a; Thiéblemont et al., 2019; Miramontes et al., 2021). The Ewing Terrace is associated with plastered drifts at the basinward side, but at the La Plata Terrace no plastered drifts could be recognised (Hernández-Molina et al., 2009; Preu et al., 2013). Two channels where found in the landward side of the Ewing Terrace that were recently reclassified as moats due to the evidence of sedimentation and its association with a separated mounded drift (Fig. 2; Bozzano et al., 2011, Bozzano et al., 2021; Preu et al., 2012, Preu et al., 2013; Voigt et al., 2013; Steinmann et al., 2020). Steinmann et al. (2020) described the southern moat for the purpose of analysing coldwater corals in close proximity to this moat. In the moat, Steinmann et al. (2020) reported current speeds decreasing from south to north and oscillating between 3 and $52 \mathrm{~cm} / \mathrm{s}$. Bozzano et al. (2021) described several morphological depressions hosting dropstones of an Antarctic Peninsula and Subantarctic islands origin.

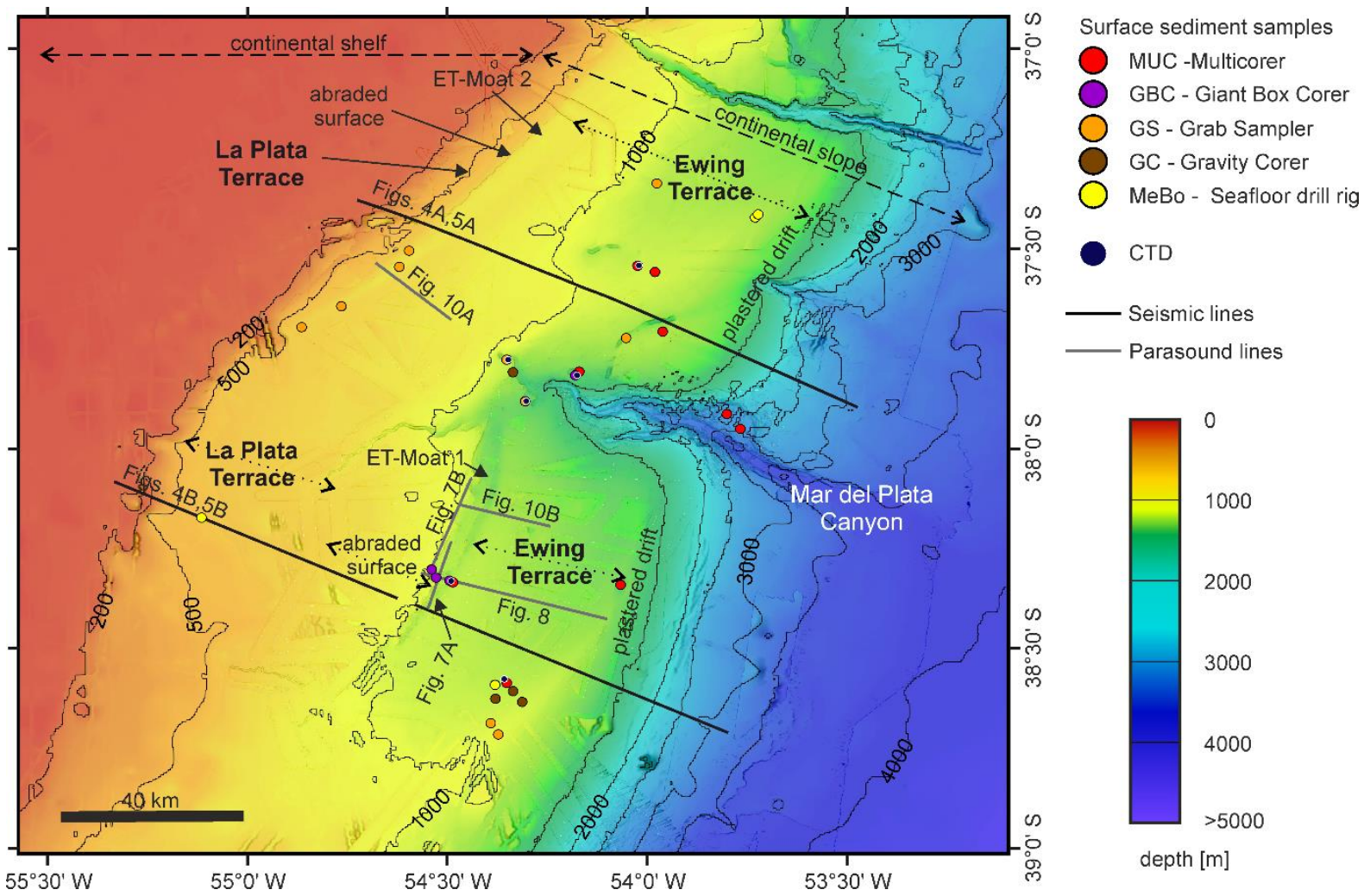

Fig. 2. Bathymetric map of the study area showing the location of the main morphological and contouritic features, surface sediment samples, CTD stations, seismic and Parasound profiles. The first contour line at $200 \mathrm{~m}$ indicates the approximate location of the continental shelf break. The deeper contour lines are every 500 m. See Fig. 1 for location. 
The prominent MdP Canyon crosses the Ewing Terrace between 1000 and 4000 m water depth (Krastel et al., 2011). The canyon is disconnected from the continental shelf and it has been excluded that it ever had a direct connection (Krastel et al., 2011). Turbidity currents in the canyon were active from the Last Glacial Maximum to the late deglacial (Warratz et al., 2019). During sea-level highstands, most of the sediments from the Río de la Plata plume were transported northwards and did not directly reach the zone around the MdP Canyon (Razik et al., 2015a). The MdP Canyon acts in part as a sediment trap for sediments transported along the Ewing Terrace by bottom currents (Voigt et al., 2013; Warratz et al., 2019).

\section{Materials and methods}

\subsection{Oceanographic dataset}

Ocean current velocities were measured with a $38 \mathrm{kHz}$ vessel-mounted Acoustic Doppler Current Profiler (VM-ADCP) during the R/V SONNE cruise SO260 in January-February 2018 (Kasten et al., 2019). These short-term measurements are used to understand small-scale oceanographic phenomena (e.g. eddies and local acceleration) and changes in bottom currents that can be linked to the underlying morphology. The $38 \mathrm{kHz}$ VM-ADCP system was configured to operate in a long range narrow band mode with a $16 \mathrm{~m}$ depth cell which leads to a depth range of over $1000 \mathrm{~m}$. The exact maximum range depends on the area. During SO260 the ADCP reached a maximum of $1600 \mathrm{~m}$. Thus, in some areas, e.g. inside the MdP Canyon, no analysis of near-bottom currents is possible. The data were processed with the Cascade V7.2 software, using a horizontal grid cell size of $1 \mathrm{~km}$ and vertical grid cell size of $16 \mathrm{~m}$. For analyses of the currents near the sea-surface, the average velocity between 50 and $150 \mathrm{~m}$ depth below sea surface was calculated. For analyses of the near-bottom current the average velocity between 150 and $200 \mathrm{~m}$ above seafloor was calculated. In the lower $150 \mathrm{~m}$ above the seafloor the data quality is too poor to be used with confidence (similar to Steinmann et al. (2020)). To check that the data quality between 150 and $200 \mathrm{~m}$ is good we also calculated 
the average between 150 and $350 \mathrm{~m}$ above the seafloor. Since the results are very similar and the interpretation does not change we will only show the data between 150 and $200 \mathrm{~m}$ above the seafloor. Furthermore, Steinmann et al. (2020) showed that the selection of this level is a reasonable approximation of bottom currents since, in this particular area, the vertical shear of the along-slope velocity between these depths is low.

The Conductivity, Temperature and Depth (CTD) data were acquired using a Sea-Bird 911 plus and were used to identify the different water masses in the study area at the time of the R/V SONNE cruise SO260 (Fig. 1) (Kasten et al., 2019). Typically, the CTD profiles were collected down to $50 \mathrm{~m}$ above the ocean floor.

As the direct current observations are only useful to depict the circulation over a limited region at the time of the cruise, we use high-resolution ocean reanalysis to better understand the large-scale and long-term circulation. The Mercator Ocean reanalysis (GLORYS12) delivers daily mean values (temperature, salinity, currents, sea-ice, and sea level) over the period 1993-2017 as part of the Copernicus Marine Environment Monitoring Service (CMEMS, http://marine.copernicus.eu/) and assimilates satellite and in-situ observations to present realistic circulation and water mass patterns (Lellouche et al., 2018). The model uses the ETOPO bathymetry (Fig. S1 of the supplementary material). The reanalysis in the study region was validated with direct observations including current measurements at depth (Artana et al., 2018). The resolution of the model is $1 / 12^{\circ}$ in horizontal and it has 50 vertical levels with variable spacing. The vertical resolution is $1 \mathrm{~m}$ near the sea surface and increases downward to $450 \mathrm{~m}$ in the deepest layers. In the 450 and $1400 \mathrm{~m}$ water depth range, the model vertical resolution varies between 80 and $200 \mathrm{~m}$.

\subsection{Geological and geophysical dataset}

Multibeam bathymetry was acquired during cruise SO260 in 2018 with a hull-mounted Kongsberg Simrad system EM122 operating at a nominal frequency of $12 \mathrm{kHz}$ (swath opening angle across track up to $150^{\circ}$, the opening angle of each beam is $0.5^{\circ} \times 1^{\circ}$, equidistant mode) (Kasten et al., 2019). Processing and gridding were carried out using the open-source 
software MB-Systems. This data set was used to construct a grid with a $25 \mathrm{~m}$ cell size for detailed analysis of two moats in the study area. A combined grid with a $100 \mathrm{~m}$ resolution was computed with MB-Systems (Fig. 2) using previously collected multibeam data acquired during R/V Meteor cruise M78/3 in 2009 (Kongsberg Simrad system EM120) and R/V Meteor cruise M49/2 in 2001 (Atlas Hydrosweep system DS2) for the analysis of the larger area. Data from the GEBCO grid (General Bathymetric Chart of the Oceans; GEBCO Compilation Group (2020); https://www.gebco.net/) at 15 arc-second intervals are used in areas where no multibeam bathymetry is available. The resulting bathymetric grid has been visualised with the open-source software QGIS (QGIS 3.12).

For detailed analyses of sub-bottom morpho-sedimentary features, we used sediment echosounder data collected with a hull-mounted narrow-beam parametric PARASOUND P70 system during cruise SO260 (Kasten et al., 2019). The PARASOUND system makes use of the parametric effect to produce a secondary low frequency based on two primary high frequencies (for details, see Grant and Schreiber, 1990)). For the analyses of the subseafloor, the secondary low frequency, which was set to $4 \mathrm{kHz}$, was used. This results in a vertical resolution of a few decimetres. A despike algorithm was applied to remove noise bursts from crosstalk with other sounding systems using the software package VISTA Desktop Seismic Data Processing Software (Schlumberger). To enhance reflector coherency, the envelope was calculated and visualised with 'The Kingdom Software’ (IHS Markit).

The high-resolution multi-channel reflection seismic data set was acquired during R/V Meteor cruise M49/2 in 2001 (Spieß et al., 2002). The seismic data were previously processed and analysed in Preu et al. (2012) and Preu et al. (2013). In this study, the two longest available seismic profiles on both sides of the MdP Canyon were used for a joint interpretation of the seafloor sedimentary structures together with oceanographic results from model outputs. These profiles are the most representative ones because they cover the entire La Plata and Ewing Terraces and are perpendicular to the flow direction making it easier to understand the geology and oceanography together. Seismic profiles were acquired with an 
analogue streamer from the University of Bremen. The streamer has 96 channels over a length of $600 \mathrm{~m}$. As an acoustic source, a 1.7 L Gl-Gun (TMSODERA) with a main frequency of 100 $500 \mathrm{~Hz}$ was used. This results in a vertical resolution of a few metres. The data set was processed with the software package 'VISTA Desktop Seismic Data Processing Software' (Schlumberger) following standard seismic procedures including bandpass filtering and common mid-point (CMP) binning. CMP bin size varies among profiles between 5 and $10 \mathrm{~m}$ depending on data quality and coverage. After the CMP stacking a residual static correction and finite-difference time migration was calculated (Preu et al., 2012, Preu et al., 2013). For interpretation of the data, the software package 'The Kingdom Software' (IHS Markit) was used.

Sediment samples were collected during the R/V SONNE cruise SO260 and the R/V Meteor cruise M78/3 using different sampling methods: giant box corer, multicorer, grab sampler, seafloor drill rig and gravity corer (Krastel and Wefer, 2012; Kasten et al., 2019). When available we used sediment samples that where derived with a Multicorer or a Giant Box Corer because it is most suitable for surface sediment sampling. Grain size analyses for particles between 0.04 and $2000 \mu \mathrm{m}$ were performed on bulk sediment samples with a Beckman Coulter Laser LS 13320 at MARUM laboratories using Sodium hexametaphosphate as a dispersant. We also used grain size measurements from previous studies to get a better understanding of the overall sediment dynamics, which are available on PANGAEA (Frenz et al. (2003b) https://doi.pangaea.de/10.1594/PANGAEA.95396; and Razik et al. (2015b) https://doi.pangaea.de/10.1594/PANGAEA.843433).

\subsection{Nomenclature}

For classifying the different observed contouritic features, we follow the nomenclature of Faugères et al. (1999), Stow et al. (2002b) and Rebesco et al. (2014). Plastered drifts are usually located on a gentle slope and are characterised by a broad, slightly mounded and convex geometry. They are associated with contourite terraces on the landward side, which are relatively flat surfaces (Miramontes et al., 2021). The limits of the contouritic terraces are 
marked by a significant increase in the slope gradient over a distance of several kilometres. In the seismic and Parasound data the limits are further identified as either an abraded/erosion surface or a transition to a plastered drift. Separated mounded drifts are more mounded than plastered drifts and often associated with steeper slopes, from which they are detached by a distinct erosional contourite channel or a non-depositional moat (Rebesco et al., 2014).

For the names of the different features in this region (e.g. terraces and canyons), we follow the widely accepted nomenclature of previous papers that described these structures to some extent (Urien and Ewing, 1974; Hernández-Molina et al., 2009, Hernández-Molina et al., 2016a; Krastel et al., 2011; Preu et al., 2012, Preu et al., 2013; Voigt et al., 2016; Warratz et al., 2017, Warratz et al., 2019). The southern moat in the study area was named Ewing Terrace Moat by Steinmann et al. (2020) and is here referred to as Ewing Terrace Moat 1 (ETMoat 1). As our study area extends further north and includes a second moat located north of the MdP Canyon that is also up-slope the Ewing Terrace, we named it Ewing Terrace Moat 2 (ET-Moat 2). The ET-Moat 2 was previously named La Plata Terrace Moat (Bozzano et al., 2021). Since this moat is disconnected from the La Plata Terrace by an erosional surface visible in seismic and Parasound data we find it more accurate to name it ET-Moat 2. The term 'bottom current' is used in a general way for all currents related to oceanographic processes flowing near the seafloor and does not refer to any specific origin, flow direction or velocity (Rebesco and Camerlenghi, 2008).

\section{Results}

\subsection{Modelled bottom currents}

Simulated bottom currents averaged over 25 years show that the dominant flow direction is towards the N-NE (Figs. 3A and 4). The Malvinas Current affects most of the upper and middle slope down to depths of about $1600 \mathrm{~m}$ south of the MdP Canyon and about $1300 \mathrm{~m}$ north of the canyon (Figs. 3A and 5). Following the model, the Malvinas Current splits near the seafloor (SW part of study area) into three branches, here referred to as MC 1, MC 2 and MC 3 (Figs. 3A and 5). The strongest mean bottom currents in the study area, reaching up to 
$25 \mathrm{~cm} / \mathrm{s}$, are located at about $1000 \mathrm{~m}$ water depth in the zone where the Malvinas Current splits into three branches (Fig. 3A). MC 1 flows along the shelf edge and upper slope (at 200 $\mathrm{m}$ water depth), along the La Plata Terrace, with average near-bottom current speeds of 8 $\mathrm{cm} / \mathrm{s}$. MC 2 flows along the slope (abraded surface $\sim 700 \mathrm{~m}$ ) between the La Plata Terrace and the Ewing Terrace with an average speed of $8 \mathrm{~cm} / \mathrm{s}$ (Figs. 3A and 5). MC 1 and 2 remerge downstream at the La Plata Terrace, west of MdP Canyon. These inner branches of the Malvinas Current $(\mathrm{MC} 1+2)$ flow in the NE direction to $\sim 36^{\circ} \mathrm{S}$. North of this latitude bottom currents are mainly driven by the Brazil Current and flow south-eastwards at the shelf edge and upper slope (Fig. 3A). The deepest branch of the Malvinas Current (MC 3) flows northeastward along the Ewing Terrace $(\sim 1200 \mathrm{~m})$ and decreases in speed from 25 to $5 \mathrm{~cm} / \mathrm{s}$ (over $60 \mathrm{~km}$ ) as the terrace widens and the slope orientation changes to north-south (Fig. 3A). Even though the speed decreases, the mean near-bottom current at the middle slope (including Ewing Terrace) continues to flow northeastwards beyond $36^{\circ} \mathrm{S}$ (Fig. 3A). The two outer Malvinas Current branches, flowing over the abraded surface (MC2) and over the basinward limit of the Ewing Terrace (MC3), have their maximum mean northeastward velocity at about 500 and $1000 \mathrm{~m}$ water depth, respectively (Fig. 5).

The Malvinas Current carries different water masses in the study area, based on model potential density: the SASW from the surface down to $\sim 500 \mathrm{~m}$ water depth, the AAIW from $\sim 500$ to $\sim 1100 \mathrm{~m}$ and the UCDW below $\sim 1100 \mathrm{~m}$ (Fig. 4, Fig. 5). The shallowest branch of the Malvinas Current (MC 1) contains SASW, while the intermediate branch (MC 2) contains AAIW and the deepest branch (MC 3) is at the interface between the AAIW and the UCDW (Fig. 4, Fig. 5). The interface between the AAIW and the UCDW is located at the Ewing Terrace (Fig. 4). On average all water masses (SASW and AAIW) over the La Plata Terrace flow towards the N-NE until $\sim 36^{\circ} \mathrm{S}$ (Fig. 4). Similarly, the mean bottom currents at the Ewing Terrace also flow towards the N-NE (Figs. 3A and 4). In the study area the influence of the Brazil Current, which flows towards the S-SE, is only noticeable close to the sea surface in the region above the Ewing Terrace (Fig. 4). The MdP Canyon influences the bottom current flow direction, leading to redirection of N-NE flowing water to the NE (Fig. 3A). 

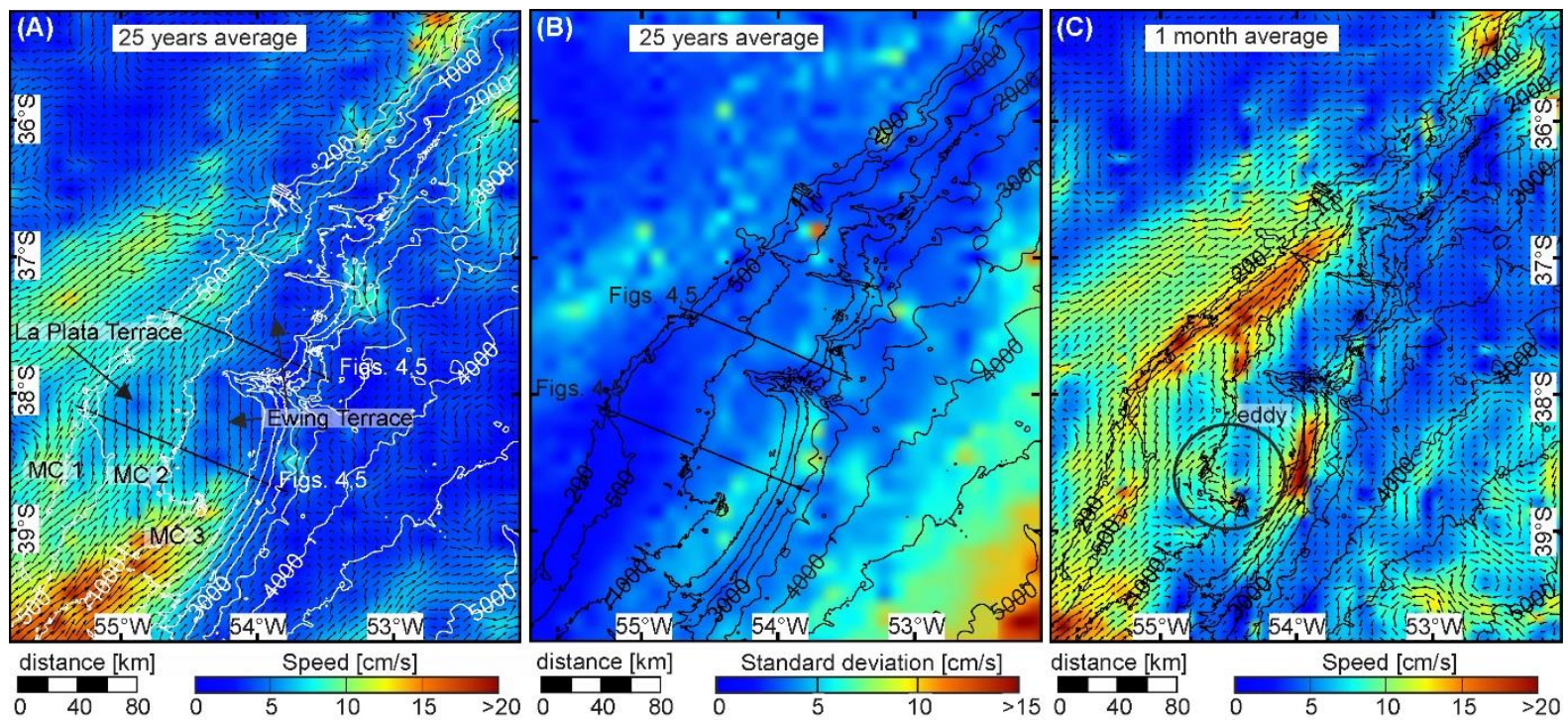

Fig. 3. (A) Modelled mean bottom velocity over 25 years; $(B)$ modelled standard deviation of the velocity $\underline{\sigma}(=\sqrt{E K E})$ over 25 years; and $(C)$ Modelled mean bottom velocity from 12/01/2012 to $14 / 02 / 2012$. Note that the scale for the speed and the standard deviation is not the same. MC 1-3 refers to three branches of the Malvinas Current near the seafloor.

The standard deviation of modelled bottom currents over 25 years reaches $16 \mathrm{~cm} / \mathrm{s}$ over the abyssal plain below $4000 \mathrm{~m}$ water depth and is lower over the shelf edge and continental slope, where it is mostly lower than $5 \mathrm{~cm} / \mathrm{s}$ (Fig. 3B). The variability in flow speed on the La Plata Terrace is lower than $5 \mathrm{~cm} / \mathrm{s}$. In contrast, the variability in flow speed over the Ewing Terrace is up to $10 \mathrm{~cm} / \mathrm{s}$, being highest on the offshore part of the terrace near the MdP Canyon (Fig. 3A). High bottom-current variability in this part of the Ewing Terrace is related to changes in current direction and speed. Bottom currents modelled over 1 month (JanuaryFebruary 2012) indicate that the deep branch of the Malvinas Current does not extend north of $39^{\circ} \mathrm{S}$. During that time the Ewing Terrace, and especially the offshore part at 1500-2000 m water depth, is affected by southward-flowing bottom currents that exceed $35 \mathrm{~cm} / \mathrm{s}$. In contrast, bottom currents over the La Plata Terrace show a similar pattern during JanuaryFebruary 2012 compared the 25-year average, although bottom current speeds are considerably higher during this short period of time, reaching $20 \mathrm{~cm} / \mathrm{s}$ north of the MdP Canyon (Fig. 3C). 
(A) North of MdP Canyon
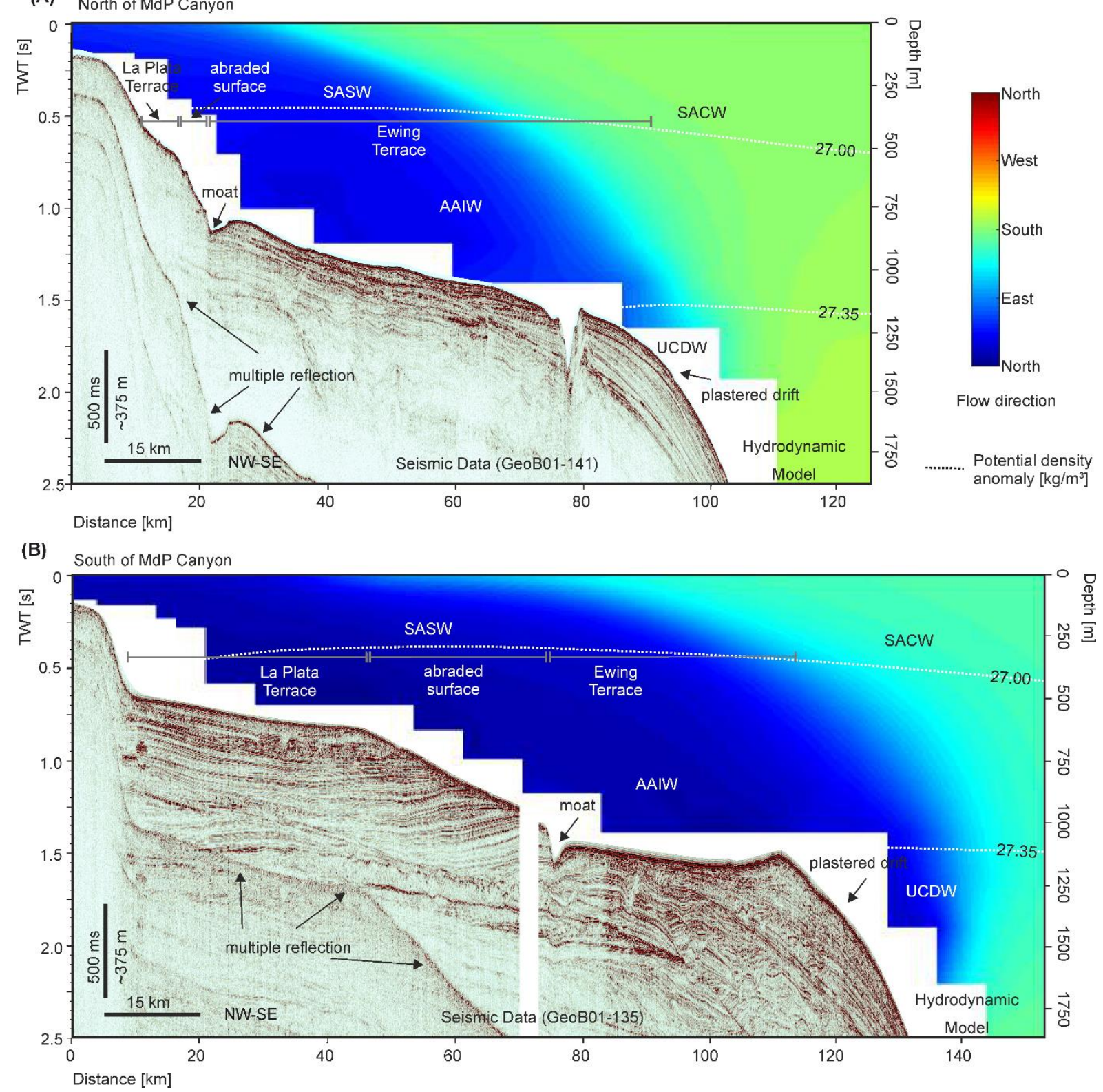

Fig. 4. Cross-sections of the hydrodynamic model showing the 25-year mean flow direction in combination with seismic sections. The white dashed lines indicate the interface of water masses calculated based on the potential density anomaly (SASW: Subantarctic Surface Water, SACW: South Atlantic Central Water, AAIW: Antarctic Intermediate Water, UCDW: Upper Circumpolar Deep Water). The location of the cross-sections is shown in Fig. 2, Fig. 4. (A) Seismic section GeoB01-141 located north of MdP Canyon and (B) GeoB01-135 located south of MdP Canyon (modified from Preu et al., 2012, Preu et al., 2013). 
(A) North of MdP Canyon
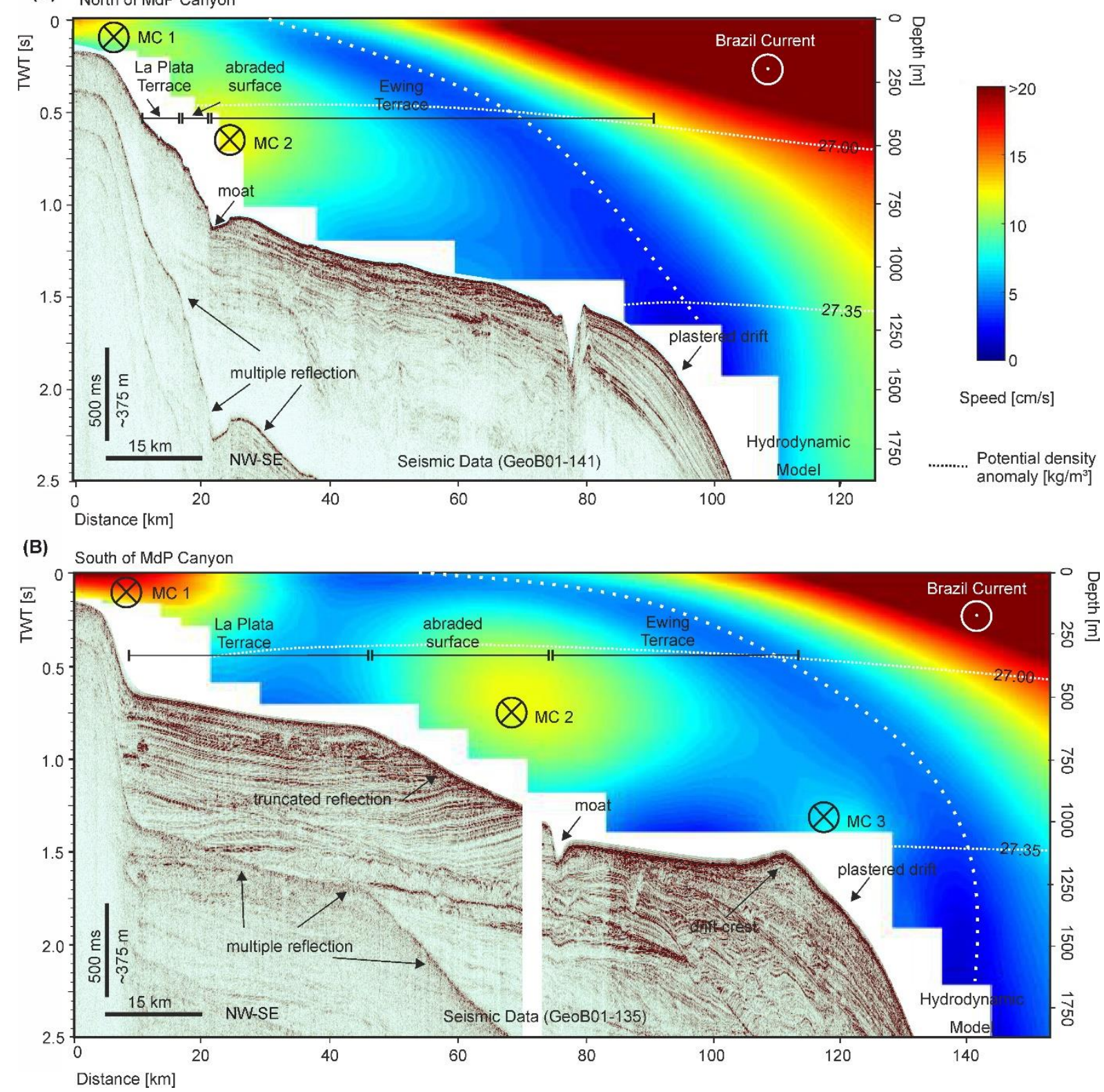

Fig. 5. Cross-sections of the hydrodynamic model showing the 25-year mean speed in combination with seismic sections. The white dashed line indicates the border between southward and northward-flowing currents (see Fig. 5). The location of the cross-sections is shown in Fig. 2, Fig. 4. (A) Seismic section GeoB01-141 located north of MdP Canyon and (B) GeoB01-135 located south of MdP Canyon (modified from Preu et al., 2012, Preu et al., 2013). 


\subsection{Direct current observations}

\section{Direct current observations}

The VM-ADCP data close to the sea surface show generally a strong $(>40 \mathrm{~cm} / \mathrm{s})$ northward current in the region over the abraded surface between the La Plata Terrace and the Ewing Terrace south of the MdP Canyon, corresponding to the Malvinas Current (Fig. 6A). In the region above the deeper part of the MdP Canyon surface currents are strong $(>50 \mathrm{~cm} / \mathrm{s})$ and flow in a southward direction, corresponding to the Brazil Current. Over the Ewing Terrace north of the MdP Canyon, the velocity is generally lower and the flow direction is more variable compared to the region south of the MdP Canyon because it corresponds to the confluence zone between the Malvinas and Brazil currents (Fig. 6A).

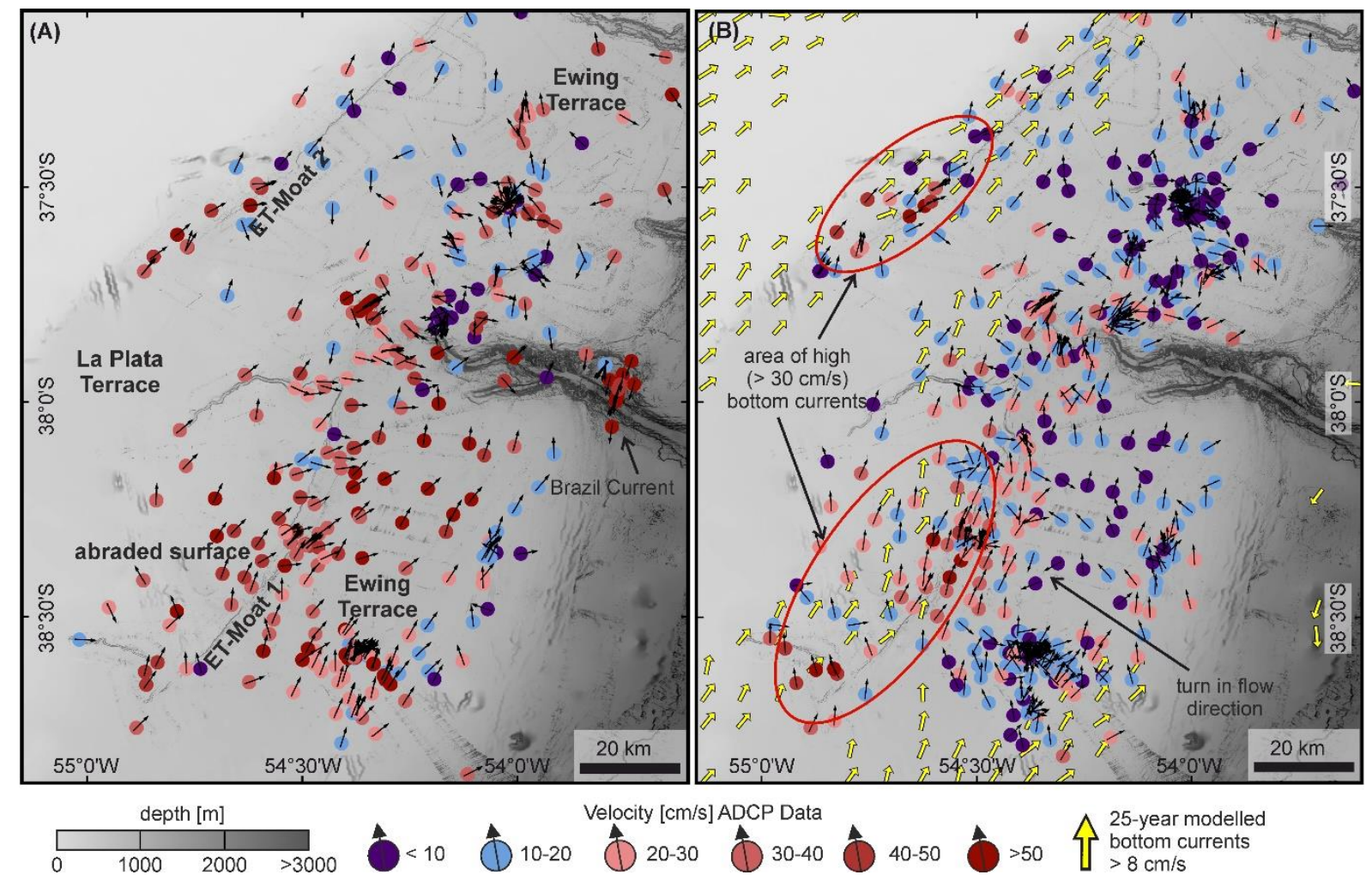

Fig. 6. (A) Near-surface velocities from ADCP data average between 50 and $150 \mathrm{~m}$ below sea surface. (B) Near-bottom velocities from ADCP data average between 150 and $200 \mathrm{~m}$ above the seafloor. Yellow arrows indicate the modelled mean bottom current velocity over 8 $\mathrm{cm} / \mathrm{s}$.

Generally, near-bottom currents are lower than surface currents (Fig. 6A and B). Similar to the reanalysis, stronger near-bottom currents are measured at the abraded surface and slower 
currents over the contourite terraces (Fig. 6B). The speed over the Ewing Terrace south of the MdP Canyon is higher $(15 \mathrm{~cm} / \mathrm{s})$ than north of the MdP Canyon $(11 \mathrm{~cm} / \mathrm{s})($ Table 1$)$. The average speed over the abraded surface is $23 \mathrm{~cm} / \mathrm{s}$. Inside ET-Moat 1 and ET-Moat 2 bottom currents are even higher, reaching average speeds of 28 and $29 \mathrm{~cm} / \mathrm{s}$ (Table 1). In all three locations, the velocity decreases northeastwards (Fig. 6B). The average measured nearbottom current over the moats is very similar but the standard deviation at ET-Moat 2 is higher than at ET-Moat 1 (Table 1). The velocity at the SW part of ET-Moat 2 is higher than at the SW part of ET-Moat 1. The velocity decreases faster in the northward direction along ET-Moat 2 than it does along ET-Moat 1 (Fig. 6B).

Table 1. Average mean near-bottom current speed for different areas: the Ewing Terrace south and north of the MdP Canyon, the slope connecting the La Plata Terrace with the Ewing Terrace (abraded surface) and the moats south and north of the MdP Canyon (ET-Moat 1 and 2).

\begin{tabular}{|l|l|l|}
\hline & $\begin{array}{l}\text { Mean speed: ADCP } \\
\text { measurement }[\mathrm{cm} / \mathrm{s}]\end{array}$ & $\begin{array}{l}\text { Standard deviation: ADCP } \\
\text { measurement [cm/s] }\end{array}$ \\
\hline Ewing Terrace South & 15 & 13 \\
\hline Ewing Terrace North & 11 & 7 \\
\hline Abraded surface & 23 & 12 \\
\hline ET-Moat 1 (south) & 28 & 11 \\
\hline ET-Moat 2 (north) & 29 & 17 \\
\hline
\end{tabular}

Over ET-Moat 1 the velocity is higher close to the bottom $(800-1000 \mathrm{~m})$ than at mid-depth (400-800 m) (Fig. 7A). In contrast, currents above the abraded surface generally decrease with increasing depth (Fig. 7B). The profile perpendicular to the ET-Moat 1 confirms that the higher velocity at depth is only a local feature over the moat and does not affect the entire water column (Fig. 8A). Furthermore, this profile shows lower velocities over the Ewing Terrace (Fig. 8A). The near-bottom flow at $7-15 \mathrm{~km}$ distance along the profile turns $180^{\circ}$ and thus flows southward. This flow reversal occurs only close to the seafloor and does not reach the sea surface (Fig. 8B). In this turn, the speed increases and reaches locally up to $20 \mathrm{~cm} / \mathrm{s}$ near the seafloor (Fig. 8A). 

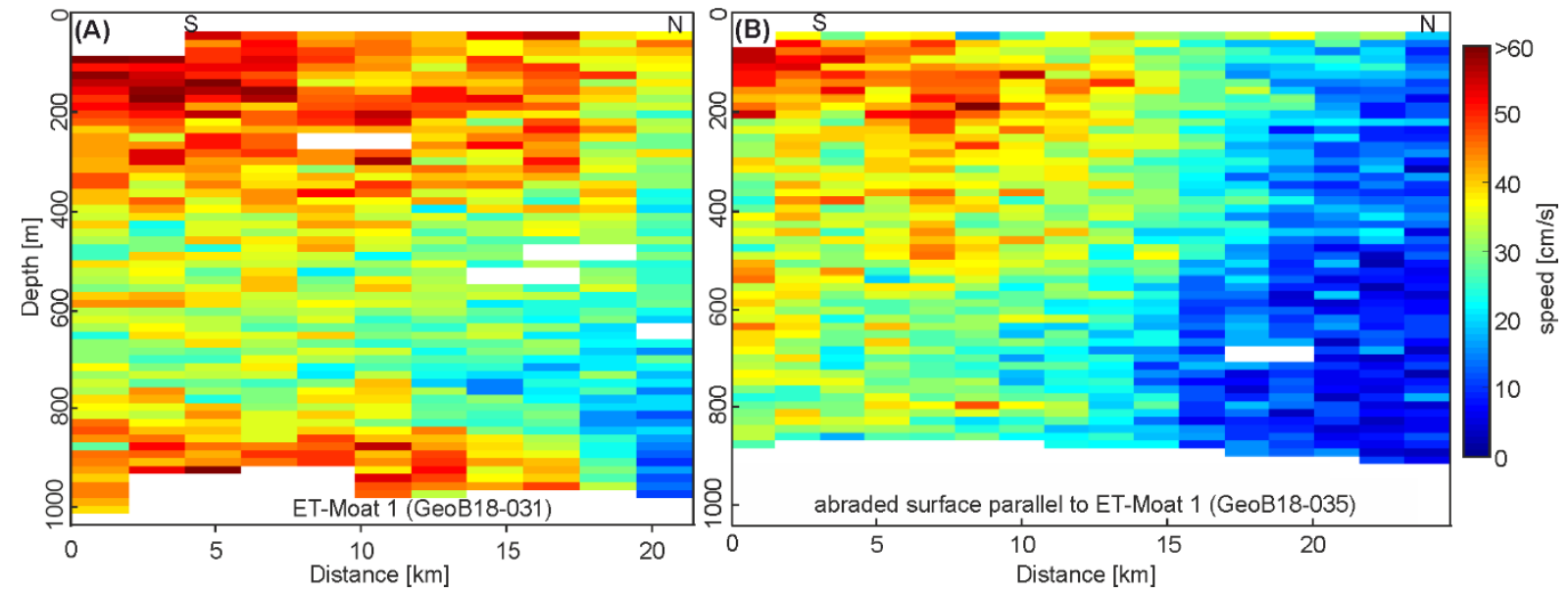

Fig. 7. (A) ADCP cross-section showing the speed over and parallel to ET-Moat 1 and $(B)$ ADCP cross-section parallel to the slope connecting the La Plata Terrace with the Ewing Terrace. The sections are parallel to each other. See Fig. 2 for location.

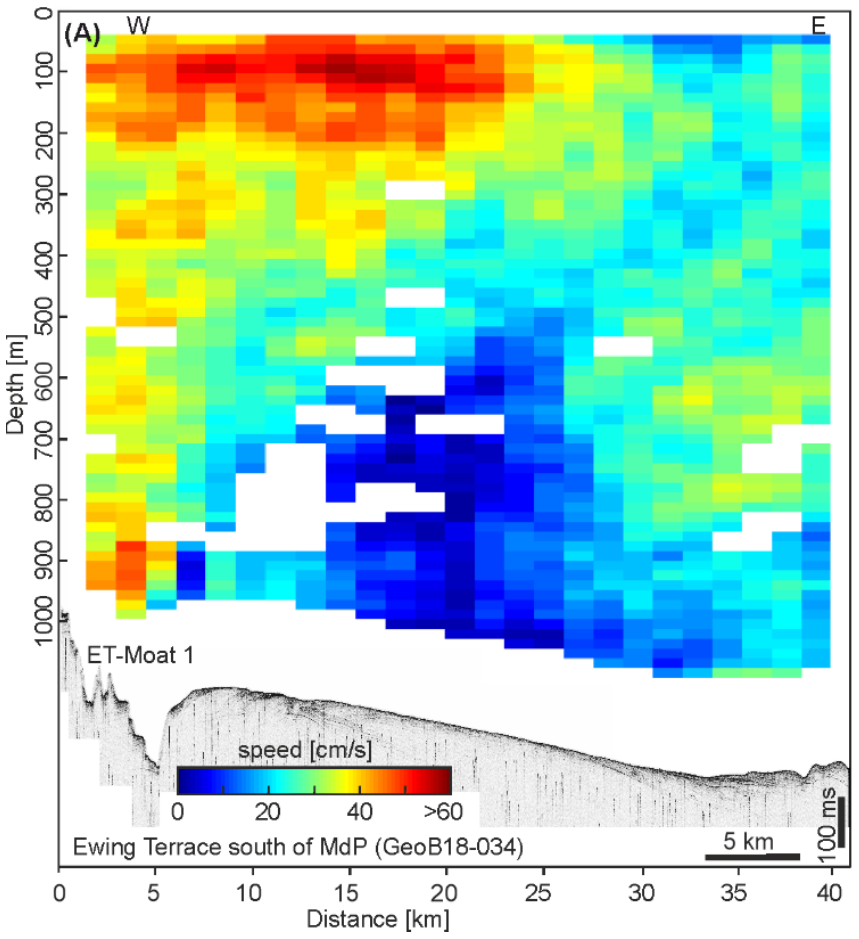

(B)

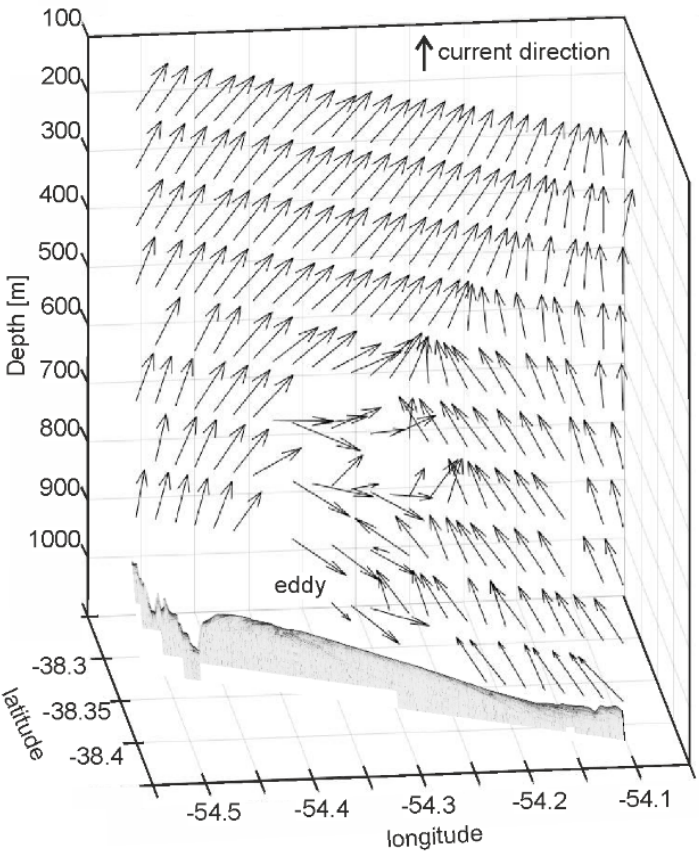

Fig. 8. (A) ADCP cross-section showing the speed across the southern Ewing Terrace in combination with Parasound data. Note that ADCP data and Parasound data are not in the same vertical scale. (B) ADCP cross-section showing the current flow direction with arrows. An average mean velocity over $50 \mathrm{~m}$ is shown every $100 \mathrm{~m}$ below the sea surface. See Fig. 2 for location. 


\subsection{Seafloor morphology and sediment architecture}

The upper and middle slope of the northern Argentine continental margin are characterised by the presence of two contourite terraces separated by an abraded surface that shows truncated parallel reflections (Fig. 2, Fig. 4; see also Preu et al., 2012, Preu et al., 2013). The deeper contourite terrace (Ewing Terrace) is associated with a plastered drift in basinward direction (Fig. 2, Fig. 4). The La Plata Terrace is the shallowest contourite terrace. South of the MdP Canyon, it is located at $500-600 \mathrm{~m}$ water depth, has a width of $\sim 40 \mathrm{~km}$ and an average slope of $0.3^{\circ}$. North of the MdP Canyon the width of the La Plata Terrace decreases drastically (Fig. 5A). The abraded dipping basinward surface that separates both terraces has a width of $25 \mathrm{~km}$, an average slope of $0.7^{\circ}$ (Fig. 5B). The characteristics of the Ewing Terrace change north and south of the MdP Canyon. South of the MdP Canyon, it is located at 1000$1400 \mathrm{~m}$, between the abraded surface and the plastered drift. The terrace deepens towards the MdP Canyon. It is $\sim 40 \mathrm{~km}$ wide and has a convex morphology due to the presence of a mounded deposit on top of the plastered drift that creates a topographic high (drift crest). North of the MdP Canyon, the Ewing Terrace is located at $800-1400 \mathrm{~m}$ between the abraded surface landwards and the plastered drifts basinwards (Fig. 5A). It is $\sim 70 \mathrm{~km}$ wide and has an average slope of $0.4^{\circ}$. The limit of the Ewing Terrace, is marked by an increase in slope, from $0.4^{\circ}$ to $>1^{\circ}$ (Fig. 5).

Two moats and parallel separated mounded drifts are located at the landward side of the Ewing Terrace (Fig. 9). ET-Moat 1 is located in a much deeper water depth ( 1150 m) than ET-Moat 2 ( $775 \mathrm{~m})$. Even though the moats are located in different water depths, they show several similarities regarding length (95 km in ET-Moat 1 and $70 \mathrm{~km}$ in ET-Moat 2), max. width (7 km in ET-Moat 1 and $6 \mathrm{~km}$ in ET-Moat $2 \mathrm{~m}$ ) and max. depth relative to the basinward mounded drift (100 m in ET-Moat 1 and $90 \mathrm{~m}$ in ET-Moat 2) (Table 2). Both moats widen towards the N-NE. ET-Moat 2 progressively widens, while ET-Moat 1 shows an abrupt widening in its central zone towards the abraded surface (Fig. 9). The water depth increases 
in the same direction. Internal terraces and scours, at the edge where the moat suddenly widens are only visible inside ET-Moat 1 (Figs. 9A and 10B).

Table 2. Key parameters of ET-Moat 1 (south of MdP Canyon) and ET-Moat 2 (north of MdP Canyon).

\begin{tabular}{|l|l|l|}
\hline & ET-Moat 1 & ET-Moat 2 \\
\hline Length (SW-NE direction) & $95 \mathrm{~km}$ & $70 \mathrm{~km}$ \\
\hline Max. width (NW-SE direction) & $7 \mathrm{~km}$ & $6 \mathrm{~km}$ \\
\hline Water depth & $1000-1300 \mathrm{~m}$ & $700-850 \mathrm{~m}$ \\
\hline $\begin{array}{l}\text { Max. depth relative to basinward } \\
\text { mounded drift }\end{array}$ & $100 \mathrm{~m}$ (deeper in NE) & $90 \mathrm{~m}$ (deeper in SW) \\
\hline
\end{tabular}

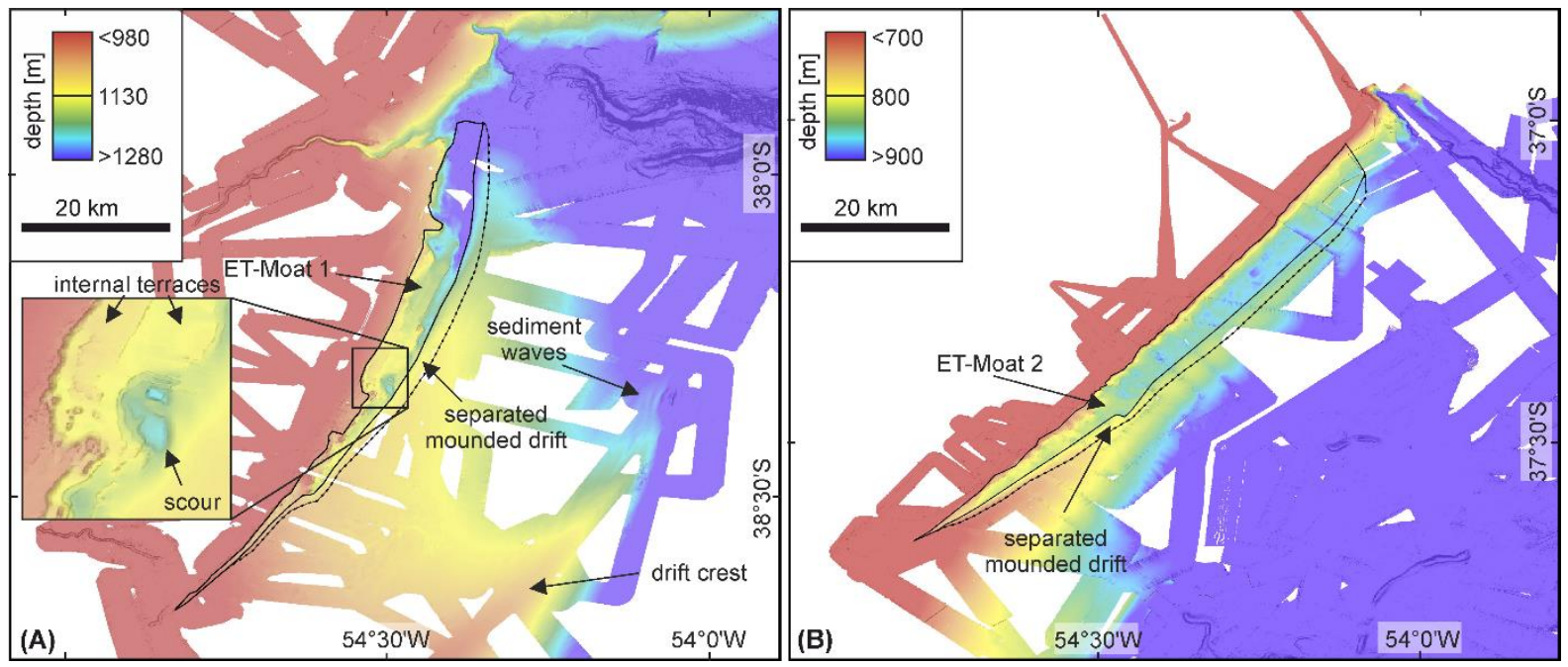

Fig. 9. Bathymetric map of the Ewing Terrace showing the main small-scale features: moats, separated mounded drifts, sediment waves and drift crest $(A)$ south and $(B)$ north of the MdP Canyon.

In the landward slope and in the deepest point of ET-Moat 1 (south of the MdP Canyon), truncated parallel reflections are visible in the Parasound data (Fig. 10B). In contrast, in ETMoat 2 (north of the MdP Canyon) and on its landward slope, Parasound penetration is very limited, and no reflections are recognised (Fig. 10A). Separated mounded drifts are identified associated with the moats and are located basinwards. These contourite drifts become thicker towards the N-NE (Fig. 9, Fig. 10). The mounded drift related to ET-Moat 1 shows continuous reflections with a sigmoidal to oblique, landward progradation pattern (Fig. 10B). The base of 
the separated mounded drifts is characterised by a widespread erosive surface. Truncations inside the separated mounded drift are abundant, suggesting frequent phases of erosion and drift construction. Adjacent to ET-Moat 2 the reflections are continuous with a sigmoidal, landward progradation pattern (Fig. 10A). The sigmoidal reflections terminate at the basinward side at one point. The base of the separated mounded drifts is not imaged. Further basinward of the contourite drift, a thin unit with continuous, wavy, parallel basinward dipping reflections of low amplitudes is deposited on top of an erosional surface (Fig. 10A). Below this unconformity, the deposits are characterised by discontinuous reflections with variable amplitudes and basinwards there are transparent units. The reflections are also generally seaward dipping but towards the erosional reflection the dip angel is reduced. On the Ewing Terrace south of the MdP Canyon continuous reflections are imaged, sometimes interrupted by small erosional surfaces close to the seafloor (Fig. 10B).
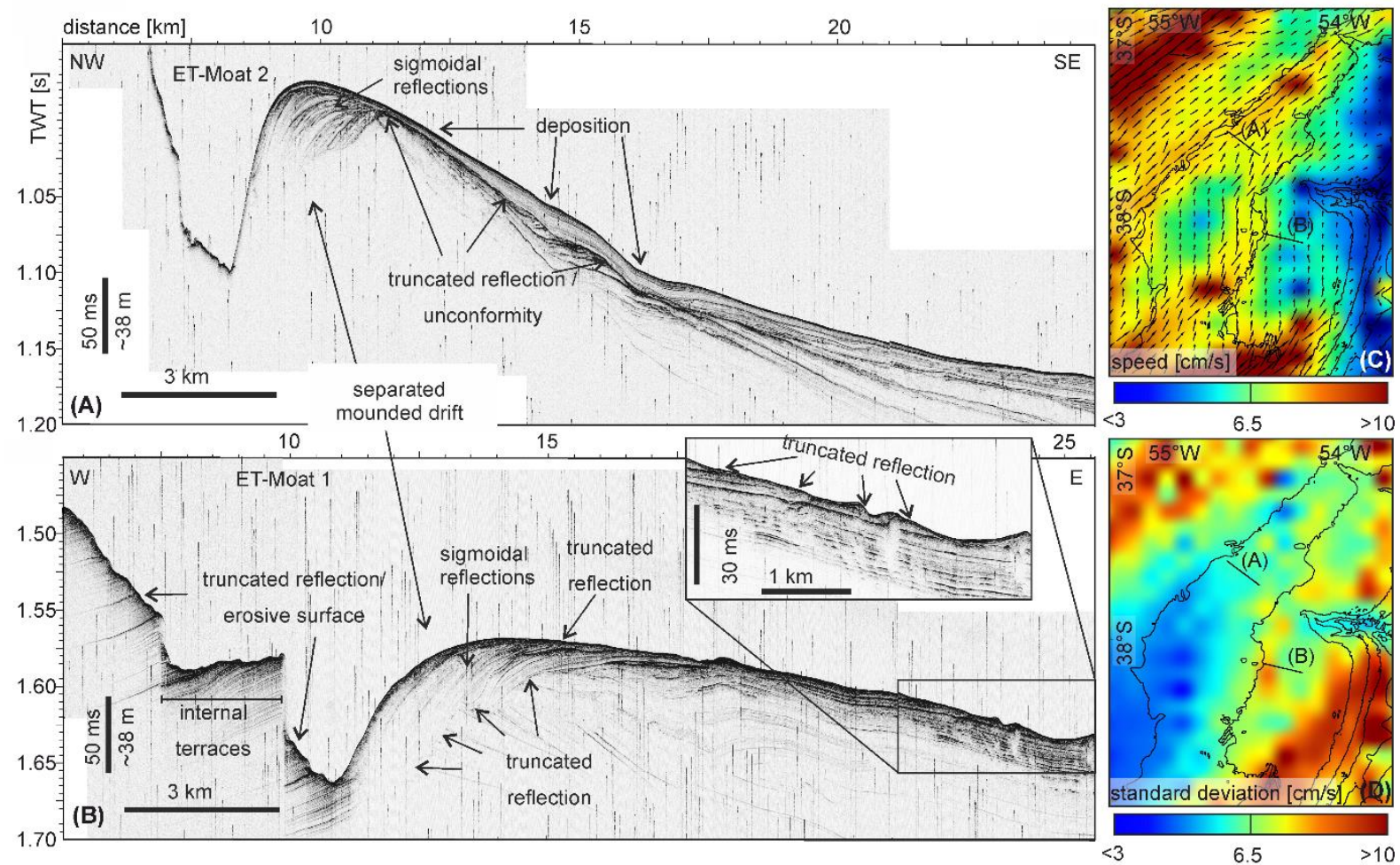

Fig. 10. Parasound data showing (A) Ewing Terrace Moat 2 north of MdP Canyon and (B)

Ewing Terrace Moat 1 south of MdP Canyon. See Fig. 10D for location. (C) Mean speed and (D) standard deviation of modelled bottom currents. 
Sediment waves are found at the seaward edge of the Ewing Terrace south of the MdP Canyon (Fig. 9A). The crests of the sediment waves are oriented parallel to the slope and migrate basinwards (up-slope of the above described drift crest that is located on top of the plastered drift). Towards the north, the drift crest becomes less distinct until the seafloor is more horizontal (Fig. 11A, B). The reflections of the sediment waves have good lateral continuity. The apparent sediment waves length and height decrease from south $(\sim 2.2 \mathrm{~km}$ wide and $\sim 20 \mathrm{~m}$ high (Fig. 11C)) to north ( 1.1 km wide and $\sim 10 \mathrm{~m}$ high (Fig. 11A)). They are located on top of an unconformity (Fig. 11A, B). The reflectivity below the sediment waves is generally low. In the south the reflections below the sediment waves also show wavy structures, whereas towards the north they are generally dipping towards the basin.

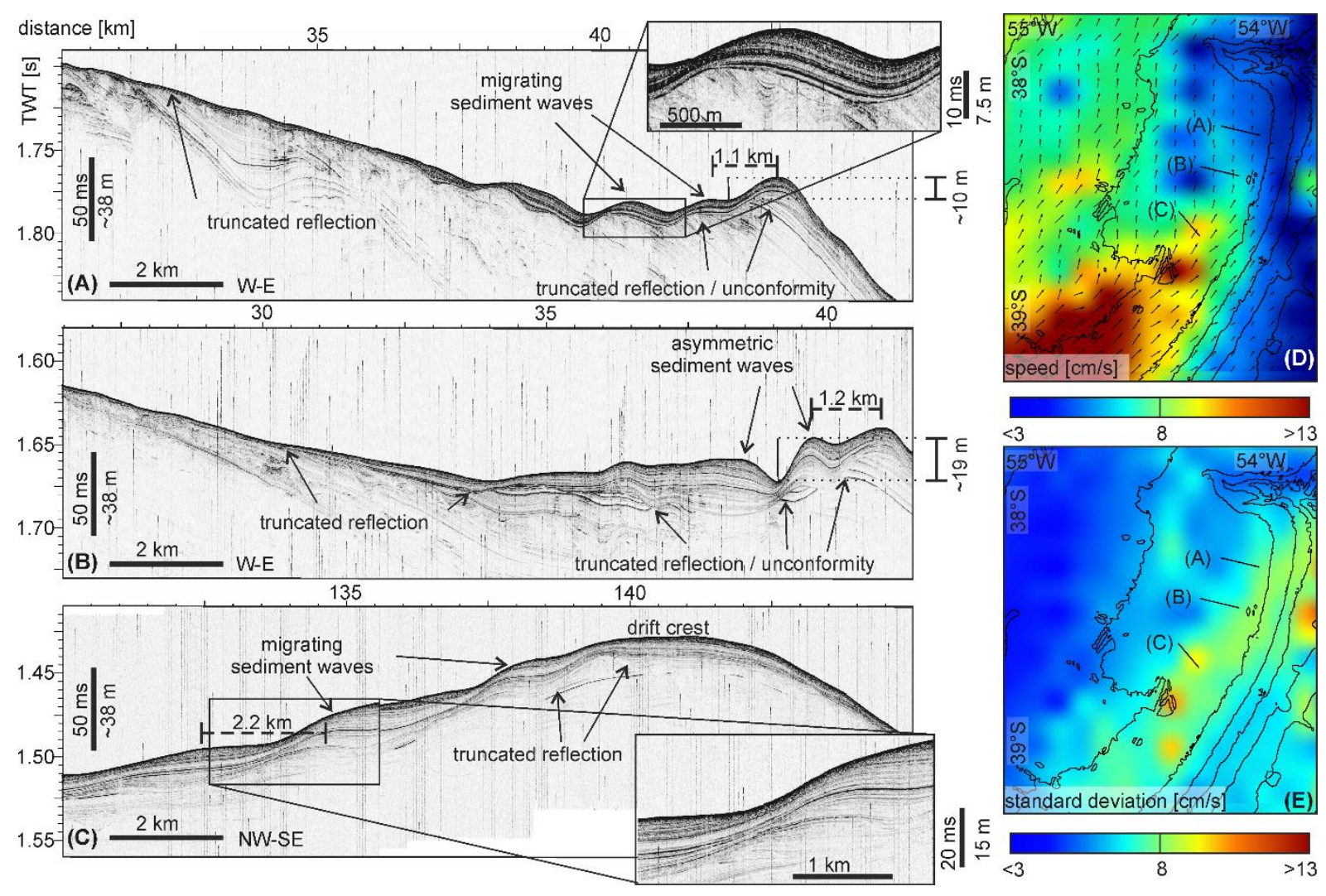

Fig. 11. $(A)(B)(C)$ Parasound data showing S-SE edge of southern Erwin Terrace (south of MdP Canyon). See Fig. 11E for location. (D) Mean speed and (E) standard deviation of modelled bottom currents. 


\subsection{Surface sediment samples}

The grain size of surface sediments generally decreases northwards and basinwards. All analysed samples on the contourite terraces (excluding the moats) can be divided in three regions with similar sediment grain size: La Plata Terrace, Ewing Terrace south of the MdP Canyon and Ewing Terrace north of the MdP Canyon. The analyses show that the median grain size is coarsest on the Ewing Terrace south of the MdP Canyon (average median grain size of $103.2 \mu \mathrm{m}$ ), less coarse on the La Plata Terrace (average median grain size of $78 \mu \mathrm{m}$ ) and finest on the Ewing Terrace north of the MdP Canyon (average median grain size of 60.1 $\mu \mathrm{m}$; Fig. 12A).
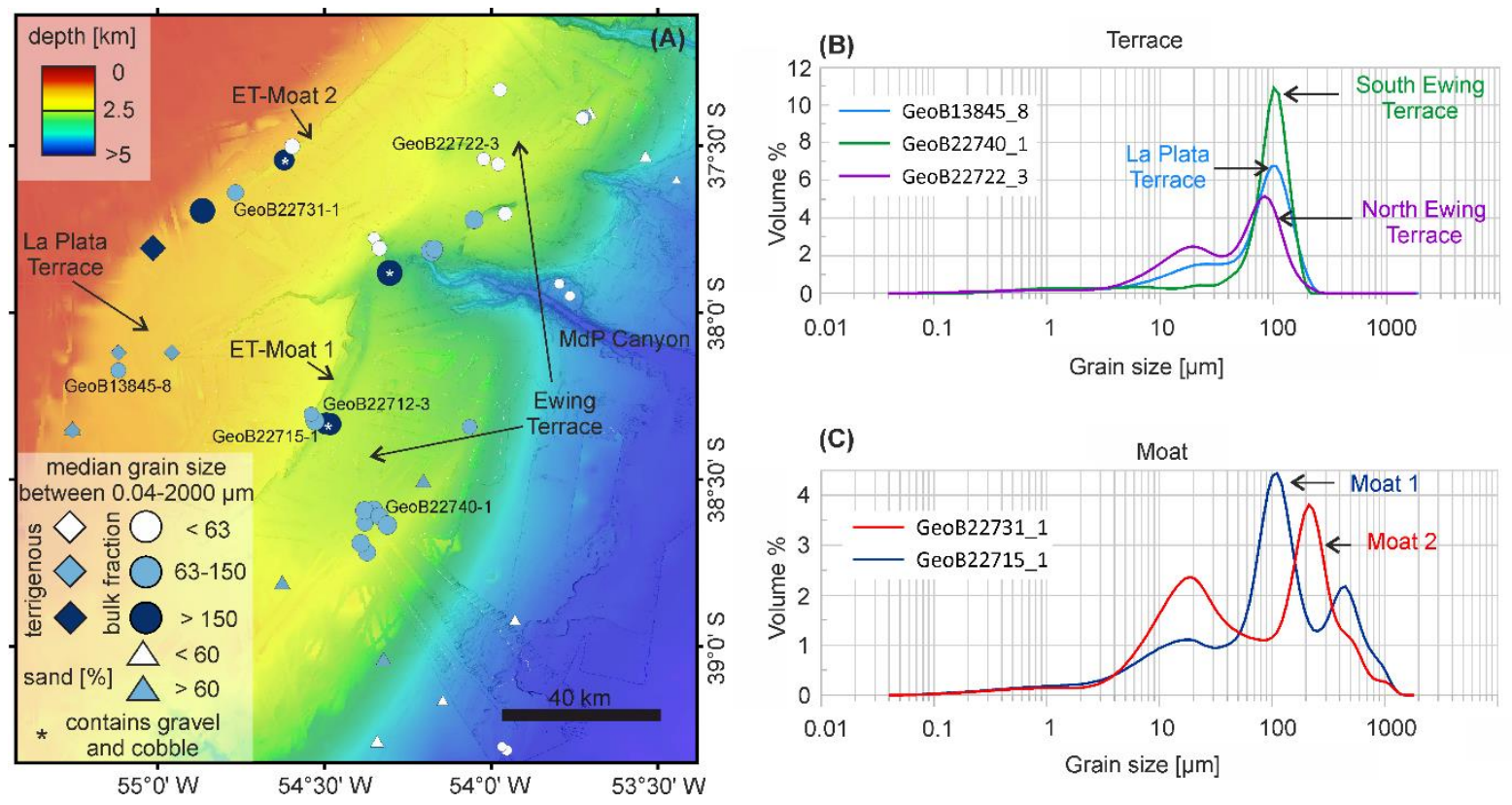

Fig. 12. (A) Median grain size of all the bulk sediment samples collected in this study (circles), median grain size of the terrigenous fraction (diamonds, Razik et al., 2015a, Razik et al., 2015b) and percentage of sand of the bulk surface sediment (triangles, Frenz et al., 2003a, Frenz et al., 2003b). (B) Grain size distribution of three samples located on the contourite terraces. (C) Grain size distribution of two samples located inside of the two moats.

On the Ewing Terrace south of the MdP Canyon, the grain size distribution typically shows only one mode at $106 \mu \mathrm{m}$, and is poorly sorted with a standard deviation of $3.45 \mu \mathrm{m}$ (Fig. 12B). 
In contrast, north of the MdP Canyon, the grain size distribution is typically bimodal with a main mode at $88 \mu \mathrm{m}$ and a secondary mode at $20 \mu \mathrm{m}$, and it is poorly sorted with a standard deviation of $3.64 \mu \mathrm{m}$. The grain size distribution on the La Plata Terrace is also bimodal with a main mode at $106 \mu \mathrm{m}$ and a second mode at $27 \mu \mathrm{m}$, and it is poorly sorted with a standard deviation of $3.67 \mu \mathrm{m}$. Sediment grain size in the moats is coarser then on the terraces and can reach median values of $173 \mu \mathrm{m}$, but its variability is very high (Fig. 12C). Sediment sample GeoB22712-3 (inside ET-Moat 1), GeoB22732-1 (inside ET-Moat 2) and GeoB22718-1 (inside MdP Canyon head area) also contain gravels and cobbles with sizes up to $10 \mathrm{~cm}$ (see Bozzano et al., 2021 for details). Several sediment samples are bioturbated and contain coldwater coral branches or fragments (Table S1, Fig. S2 of the supplementary material). Surface sediments on the small terrace inside the MdP Canyon and in the basin are much finer, with median grain sizes below $63 \mu \mathrm{m}$ and percentages of sand below $60 \%$ (Fig. 12A).

\section{Discussion}

\subsection{Bottom current dynamics over the CDS}

The Brazil-Malvinas Confluence Zone is a very dynamic area (Fig. 1), where southward flowing water from the Brazil Current encounters northward flowing water from the Malvinas Current (Piola et al., 2018; Artana et al., 2019; Piola and Matano, 2019). Current velocity measurements can resolve local intensification of speed from the current and small eddies. This is very important for linking oceanographic processes with sedimentary features. However, they lack large-scale coverage and continuity over long periods of time, which is especially important in a highly variable area like the confluence zone. This gap can be filled by numerical modelling that allows us to extend our observations in space and time, and can thus improve the understanding of long-term mean currents and short-term variability. This is especially important to drive sediment patterns (here the CDS) in geological time scales. The reanalysis covers a period of 25 years, however, contourites are developed over several thousands or millions of years. Still, the model is useful for understanding current dynamics since the modern ocean circulation and stratification pattern was already established during 
the Middle Miocene (Preu et al., 2012). Even though the ocean circulation has changed to some extent in terms of strength or position since the Middle Miocene, the patterns and processes that form the CDS are thought to have remained similar.

In the present study, we focus our analysis on the near-bottom currents and discuss the differences between currents near the seafloor and at the sea surface in the confluence zone. Former numerical simulations indicate that at the sea surface in the confluence zone, the Malvinas Current splits into two branches: the outer branch veers offshore and flows with the Brazil Current, while the inner branch subducts below the Brazil Current (Provost et al., 1995; Artana et al., 2019). Comparison of previous model results (Artana et al., 2019) with our model results (Fig. 3) show that on average the Brazil-Malvinas Confluence Zone between the northward flowing and the southward flowing currents is located further south near the surface. Our model results show additionally that the Malvinas Current at $39^{\circ} \mathrm{S}$ near the seafloor further splits into three branches that flow along the contourite terraces and over the abraded surface located between the terraces, respectively. Direct measurements at $40-41^{\circ} \mathrm{S}$ indicate that the mean Malvinas Current has an equivalent barotropic structure (Vivier and Provost, 1999). This usually indicates more homogeneous velocities throughout the water column. Thus, the described changes in velocity within the Malvinas Current might be connected to the interaction of the Malvinas Current with the Brazil Current at the confluence and to the interaction with the seafloor morphology.

Accelerated near bottom currents are important for deep-sea coral reefs because they need energetic currents to transport food particles and to inhibit burial (Roberts et al., 2006; Muñoz et al., 2012). Thus, corals are also an indicator of intense currents. Deep-sea coral reefs off Uruguay (Carranza et al., 2012) are in an energetic environment related to the Brazil Current (Franco-Fraguas et al., 2014). Cold water corals at the Argentine margin have been recognised in ET-Moat 1 and on the abraded surface (Steinmann et al., 2020) and ET-Moat 2 (Table S1 of the supplementary material) that are both controlled by high energetic cores of the Malvinas Current (Fig. 6B). 
The Malvinas Current carries different water masses (Fig. 4). Preu et al. (2013) identified different water masses at the seafloor based on all available historical hydrographic data. The extent of the NADW interaction with the seafloor based on the previous observations derived by Preu et al. (2013) is in good agreement with the southward near-bottom flow determined by the long-term average circulation derived from the ocean reanalysis (Fig. 13), suggesting that the model depicts a realistic near-bottom circulation.

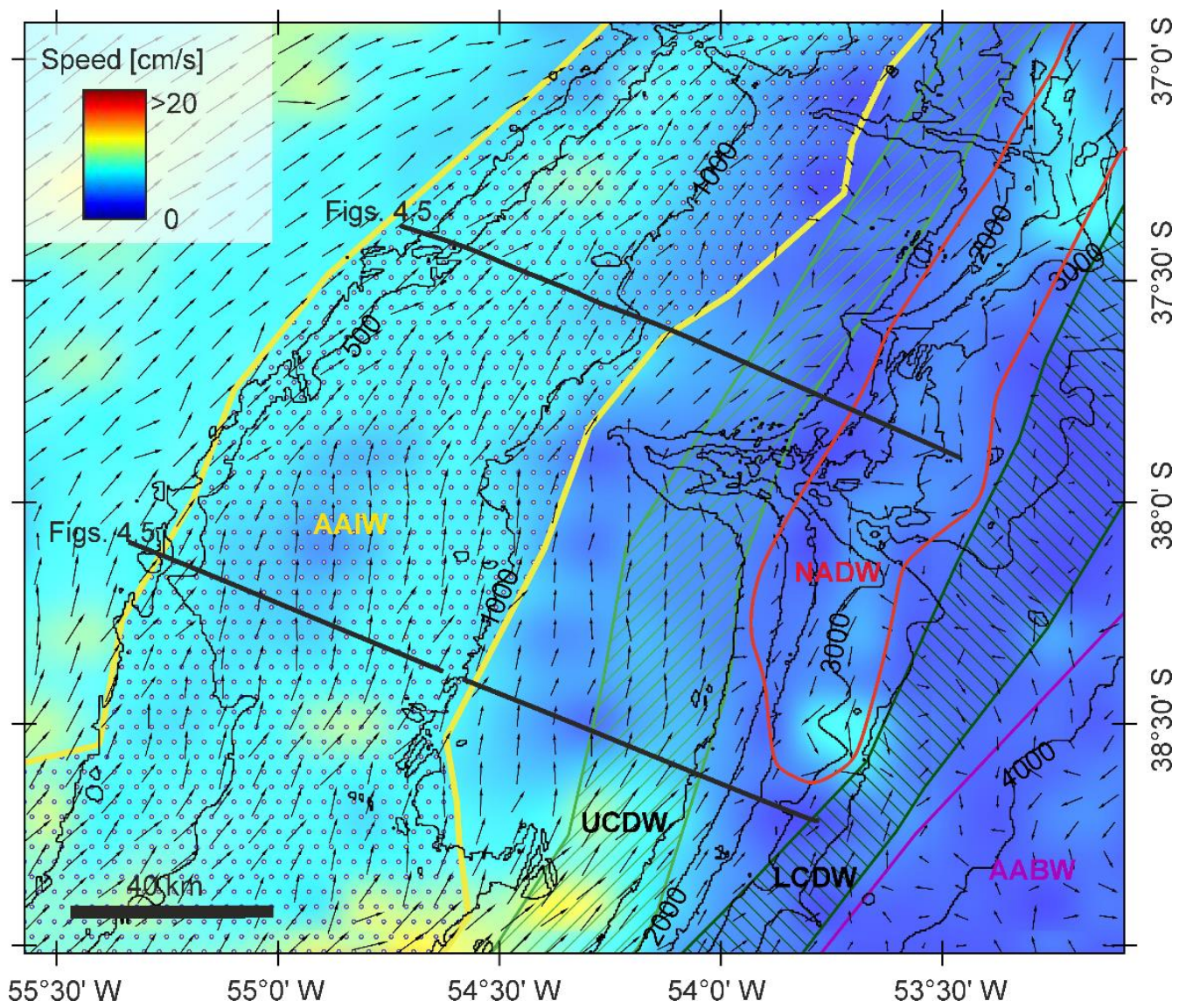

Fig. 13. Modelled bottom current velocity (over 25 years) together with an illustration of the water masses (identified from CTD data) at the seafloor (adapted from Preu et al. (2013)).

The VM-ADCP measurements show similar flow patterns as the 25-year averaged model result, but generally the measured speed is higher (Fig. 3, Fig. 6), which might be expected since it displays instantaneous measurements, in contrast the model shows the mean velocity. Artana et al. (2019) showed that especially the surface velocity variability in this zone is very high. Thus, the differences in speed probably reflect the strong flow variability in the confluence zone. The 1 -month simulation result (12/01/2012 to 14/02/2012) also shows higher 
bottom current velocity than the 25-year averaged model result (Fig. 3). It highlights the variability not only in current speed but also in current direction.

\subsection{Formation of sedimentary features}

$\underline{\text { Sediment dynamics }}$

Generally, for a constant seafloor depth a decrease in near-bottom current speed is observed from south to north in both modelled and measured currents (Fig. 3, Fig. 6). This agrees well with the northward decrease in sediment grain size of surface sediments (Fig. 12). Erosional surfaces and coarse grain size are generally an indication for strong bottom currents, whereas fine grain size is rather a sign for weak bottom currents. In order to better understand whether the observed and modelled near-bottom currents would be capable of eroding and transporting sediment, we calculated the bottom shear stress $\left(\tau=\rho u_{*}^{2}\right.$, with seawater density $\rho$ and friction velocity $u_{*}$ ) from VM-ADCP measurements. Observed bottom shear stresses reach critical shear stresses $\left(0.13-0.17 \mathrm{~N} / \mathrm{m}^{2}\right)$ for the observed sediment grain sizes $(60-130 \mu \mathrm{m}$; according to critical shield parameter for motion initiation proposed by Soulsby and Whitehouse (1997)) along the slope between the La Plata Terrace and the Ewing Terrace, as well as along the moats (Fig. 6). This shear stress corresponds to current velocities at $150 \mathrm{~m}$ above the seafloor over $30 \mathrm{~cm} / \mathrm{s}$, assuming a logarithmic relation between the friction velocity and the variation of velocity with height, a von Kármán constant equal to 0.4 and bottom roughness length equal to $0.0035 \mathrm{~m}$ (Schlichting, 1962). This prediction of sediment erosion based on the bottom shear stress agrees with the erosion visible in the Parasound data at the abraded surface between the La Plata Terrace and the Ewing Terrace as well as along the moats (Fig. 4, Fig. 5, Fig. 10).

Some contouritic features are commonly related to mean flow velocity (Stow et al., 2009; Rebesco et al., 2014) or the corresponding mean bottom shear stress (Schlichting, 1962; Soulsby and Whitehouse, 1997). But for further understanding sediment dynamics, not only the mean velocity is relevant but also the flow variability and secondary (smaller scale) 
processes (e.g. eddies) that can increase bottom shear stress on the seafloor and control contouritic processes (Thran et al., 2018; Chen et al., 2019). On the Ewing Terrace south of the MdP Canyon, we observed erosional surfaces in the Parasound data even though the mean speed is low here (Fig. 10B). Internal acceleration due to a sloping morphology can lead to flow instabilities and finally to generation of waves and eddies (Rebesco et al., 2014; Zhang et al., 2016). This phenomenon possibly occurs at the Ewing Terrace south of the MdP Canyon that is tilted slightly towards the NE (Fig. 2). Furthermore, in this area the terrace width increases and thus the contour current has more space to flow over the flat terrace (Fig. 2). This divergence of isobaths may cause a decrease in the mean flow and also lead to the development of flow instabilities. We propose that this widening leads sometimes to turbulences and eddies at the seafloor, similar to water flowing out of a channel or a river mouth (Falcini and Jerolmack, 2010). This is also reflected by a slightly enhanced flow variability on the Ewing Terrace compared to the La Plata Terrace (Fig. 3B). Furthermore, as previously described, during times when the Malvinas Current is relatively weak, the flow direction over the Ewing Terrace can turn towards the south at the basinwards edge (Fig. 3C). On the other hand, one branch of the Malvinas Current (MC 2) flows northward along the abraded surface (landwards of the Ewing Terrace). The opposite flow direction makes the occurrence of clockwise rotating eddies likely. VM-ADCP measurements and the hydrodynamic modelling results averaged over one month confirm the presence of a cyclonic eddy on the Ewing Terrace (Figs. 3C and 8B). This suggest that these eddies can lead to local erosion because shear stress can be much higher in turbulent flow compared to laminar flow (Fig. 14; Schlichting and Gersten, 2016; Yin et al., 2019). However, this change in flow direction was not observed at all ADCP profiles and is not apparent in the model derived 25year average bottom currents at the Ewing Terrace. Thus, these eddies may be transient features and there are energetic periods during which the sediment is eroded, alternating with calm periods during which sediment deposition is favoured. The non-permanent character of the eddy is probably related to the large hydrodynamic changes in the confluence zone. This variability in bottom currents may also explain that the modern seafloor on the Ewing Terrace 
is patchy in terms of erosion and deposition (Fig. 11). These new observations refine our understanding of the sediment dynamics in the vicinity of the MdP Canyon. The depositional system located further south of this study area at $\sim 45^{\circ} S$ might be different because of a more stable Malvinas Current with its main branch being located over the terrace (Piola et al., 2013).

\section{Moats and separated mounded drifts}

Moats and paleo-moats and the related separated mounded drifts are commonly used to reconstruct bottom currents because they provide a clear indication for strong bottom currents and their direction (Surlyk and Lykke-Andersen, 2007; Betzler et al., 2013). To make these reconstructions more reliable, it is necessary to study the geomorphology of active moats together with the characteristics of the flow regime. At the landward edge of the Ewing Terrace, two up-slope migrating moats are located, each with an associated separated mounded drift (Fig. 10). The morphology of the observed separated mounded drifts is not typical for a drift associated with a moat (Faugères et al., 1999; Stow et al., 2002a; Rebesco et al., 2014). Unlike here, typically, the units between the reflections become thinner leading to almost parallel, uniform reflections at the basinward side of the drift (Faugères et al., 1999; Stow et al., 2002a; Betzler et al., 2013; Rebesco et al., 2014). However, the drifts observed here clearly terminate just a few kilometres basinward of the moats. The unusual depositional character is possibly connected to the vigorous bottom currents and the intensification of near-bottom currents that was measured above ET-Moat 1 (Fig. 7A). This makes it an erosive and very sandy and even gravelly moat, and a silty-sandy separated mounded drift (Bozzano et al., 2011), while separated mounded drifts related to moats are typically mud dominated (Rebesco et al., 2014; Miramontes et al., 2016). The initiation for developing a moat might be connected to local eddies, as discussed earlier. However, it is not clear yet how the development of moats initially starts and further investigation is needed. Possibly, turbulence and small eddies occurring in the moats leading to erosion, but these cannot be resolved by the present model because of the limited resolution. A detailed understanding of flow patterns inside the moat, 
will require very high-resolution numerical modelling of bottom currents and/or extensive (mooring-based) ADCP measurements to confirm the modelling results.

The available ADCP data show that bottom currents over the moat increase locally (Fig. 8). Along- and across-slope ADCP sections confirm that this increase in flow velocity is restricted to the near-bottom currents over the moat (Fig. 7). Thus, after the moat started to form, it affected the bottom currents, probably focusing bottom currents and leading to an increase in velocity. Current speed standard deviation in ET-Moat 2 is almost twice as high as in ET-Moat 1 which could be due to a stronger decrease of speed in ET-Moat 2. Taking velocity fluctuations in turbulent flow into account (Inman, 1949), this may explain why the sediment is less sorted. When a moat abruptly widens (like ET-Moat 1), bottom currents interact with the edge of the slope possibly leading to the formation of vortices and eddies (Fig. 9). These eddies may have formed the observed scour inside the moat (Fig. 9A). This process of cutting back of the slope can be an important factor responsible for widening the contourite terrace (Preu et al., 2013). Furthermore, the ADCP data also show that as the moats widen northwards, the flow velocity decreases (Figs. 6 and 7). This has implications for the alongslope sediment transport. Sediment transported in close proximity to ET-Moat 1 by the MC2 current branch can be deposited at the MdP Canyon head (see Section 5.3).

\section{Drift crest}

The modelled bottom currents averaged over 25 years show that the flow variability over the La Plata Terrace is lower than over the Ewing Terrace. The highest flow variability is at the basinward edge of the Ewing Terrace south of the MdP Canyon where MC3 drastically decreases in speed (from 25 to $5 \mathrm{~cm} / \mathrm{s}$ over $60 \mathrm{~km}$ ) (Figs. 3B, 5B, 11E). The maximum northward extent of MC3 fluctuates and is possibly dependent on the strength of the Malvinas Current, which can explain the higher variability in speed compared to the rest of the Ewing Terrace (Fig. 3B). In this area a drift crest or morphologic high developed on the upper part of the plastered drift (Figs. 9A, 11A, 14), possibly as a result of a weakening bottom current with reduced sediment transport capacity, allowing deposition. The decrease in bottom current 
speed towards the north may also inhibit the transport of coarse sediment, favouring its deposition and forming the observed drift crest, which is mainly composed of sand, with a median grain size of $103 \mu \mathrm{m}$.

\section{Sediment waves}

The drift crest on the basinward edge of the Ewing Terrace is partly covered by several sediment waves that migrate basinwards up-slope on the drift crest (Fig. 11). Sediment waves can be formed by downslope flowing turbidity currents and along-slope flowing bottom currents (McCave, 2017). The sediment waves discussed here are not associated with any downslope submarine channel and they are thus not formed by turbidity currents. Consequently they are contouritic sediment waves and part of the CDS. Flood (1988) proposed that the lee-wave mechanism can form sediment waves under bottom currents. Lee-waves can develop within a bottom current that flows over a wavy topography (Flood, 1988), but the sediment waves initiation process is not well understood. In agreement with this theory, the sediment waves discussed here are located at the lee side of the above-described drift crest. This drift crest could possibly lead to the development of the lee-waves. Flood (1988) assumed that the sediment waves are perpendicular to the current direction. However, further theoretical analyses taking the Coriolis force into account indicate that sediment waves under bottom currents can be oblique to the flow direction (Blumsack and Weatherly, 1989; Hopfauf and Spieß, 2001). Oblique sediment waves have been observed at several places (McCave, 2017). In this study we report on sediment waves that are parallel to the direction of currents (Fig. 9, Fig. 11). This parallel orientation to the flow direction seems unlikely to be explained by lee-waves alone. Thus, other processes have to be taken into consideration. Previous research reported that internal waves can form sediment waves and dunes (Hand, 1974; Reeder et al., 2011; Droghei et al., 2016; Ribó et al., 2016; Reiche et al., 2018; Yin et al., 2019; Miramontes et al., 2020). Internal waves can propagate at density discontinuities and have been previously proposed as a cause for the development of the Ewing Terrace and the La Plata Terrace (Hernández-Molina et al., 2009; Preu et al., 2013). The suggested 
mechanism is that the internal waves can propagate at the interface of AAIW, UCDW and NADW, respectively. The sediment waves discussed here are located slightly below the interface between the AAIW and the UCDW (Fig. 14). Internal waves with an amplitude of up to $250 \mathrm{~m}$ have been reported in deep-sea environments (Van Haren and Gostiaux, 2011). Possibly, part of the energy from the internal wave propagating at the interface of AAIW/UCDW interacts with the northward bottom flow which influences the deposition of sediment waves. The formation of these sediment waves was initiated several thousands of years ago likely during times when the Malvinas Current was stronger, for example during glacial times (e.g. Voigt et al., 2013). Due to high bottom-currents, part of the top from the plastered drift was eroded forming part of the unconformity on which the sediment waves formed (Fig. 11A). In the south, sediment waves might have been already deposited below the unconformity but are not clearly visible because they are partly eroded. Their large variability in reflectivity could be related to the large glacial and interglacial changes in flow strength (e.g. Voigt et al., 2013). However, the processes leading to the formation of sediment waves are still not well understood.

\section{Terrace formation}

The initiation of the contouritic terraces formation was suggested by some authors to be related to internal waves propagating at water mass interfaces (Hernández-Molina et al., 2009, Hernández-Molina et al., 2016b; Preu et al., 2013; Ercilla et al., 2016; Yin et al., 2019; Llave et al., 2020). Other authors proposed that internal waves may be secondary processes that can form channels and dune fields on contourite terraces, but are not responsible for the original formation of the contourite terrace, which they argued is probably related to strong along-slope currents (Miramontes et al., 2019, Miramontes et al., 2020). The model derived 25-year average bottom currents and the near-bottom water mass distribution derived from CTD measurements confirm that the contouritic terraces in the northern Argentine margin (Fig. 4, Fig. 13) are roughly located at water-mass interfaces (Hernández-Molina et al., 2009; Preu et al., 2013). However, the modelled bottom currents averaged over 25 years indicate that the 
La Plata Terrace is not located at the interface of water masses carried by the Brazil Current and AAIW as suggested by Preu et al., 2013, but at the interface of SASW and AAIW (Fig. 4).

It has also been suggested that contourite terraces in the Mediterranean Sea are located in zones of relatively high geostrophic bottom currents, while plastered drifts are located in the adjacent zone of less intense bottom currents (Miramontes et al., 2019). Vigorous currents are observed and modelled only in the inner (landward) part of the contourite terraces, while the central and external (basinward) parts are affected by weaker bottom currents, although with a higher variability at the external (basinward) edge of the terrace (Fig. 3, Fig. 5, Fig. 6). Modelled and observed bottom currents are the weakest over the plastered drifts (Fig. 3, Fig. 5, Fig. 6). This current regime is also reflected in the general sediment stratigraphy of the Ewing Terrace (Preu et al., 2012). The landward part, where high currents are present, shows more evidence of erosion. As the flow weakens towards the basinward side, more deposition is possible and large plastered drifts form. On top of this general stratigraphy, secondary deposits like separated mounded drifts, drift crests and sediment waves were deposited as discussed before. We suggest that contourite terraces may have been initiated by erosion on the slope generated by the action of two water masses and their interphase trough time, being the (paleo) Malvinas Current one of the key factors that progressively cut the slope landwards, widening the contourite terrace with time. The fact that the Argentine contourite terraces are much wider and flatter than other terraces observed for instance in the Mediterranean Sea (Ercilla et al., 2016; Miramontes et al., 2019), along the Mozambican margin (Thiéblemont et al., 2019; Miramontes et al., 2020) and in the Makassar Strait (Brackenridge et al., 2020) could be related to the higher speed of near-bottom currents as part of the Malvinas Current and the long time period of erosion (since the opening of the Drake Passage). The particular flat morphology with an abrupt edge of the terraces along the Argentine margin may favour the formation of internal waves at the terrace edge, similar to those observed at the shelf break (Jackson et al., 2012), that could also favour sediment transport and erosion along the terrace. These processes are however expected to be weaker than on upper slopes and at the shelf break because of the weaker density gradient (Fig. 1B). Up to date, no internal waves could 
be directly identified near the seafloor in the study area. Magalhaes and da Silva (2017) analysed internal waves along the Malvinas Current with multispectral satellite imagery and found that most of the internal waves are located south of the study area in areas of submarine canyons. These internal waves propagate upstream of the Malvinas Current (Magalhaes and da Silva, 2017) and are thus not perpendicular to the slope. New in situ measurements close to the sea floor and modelling studies are necessary to determine the role of internal waves in the formation and the evolution of contourite terraces.

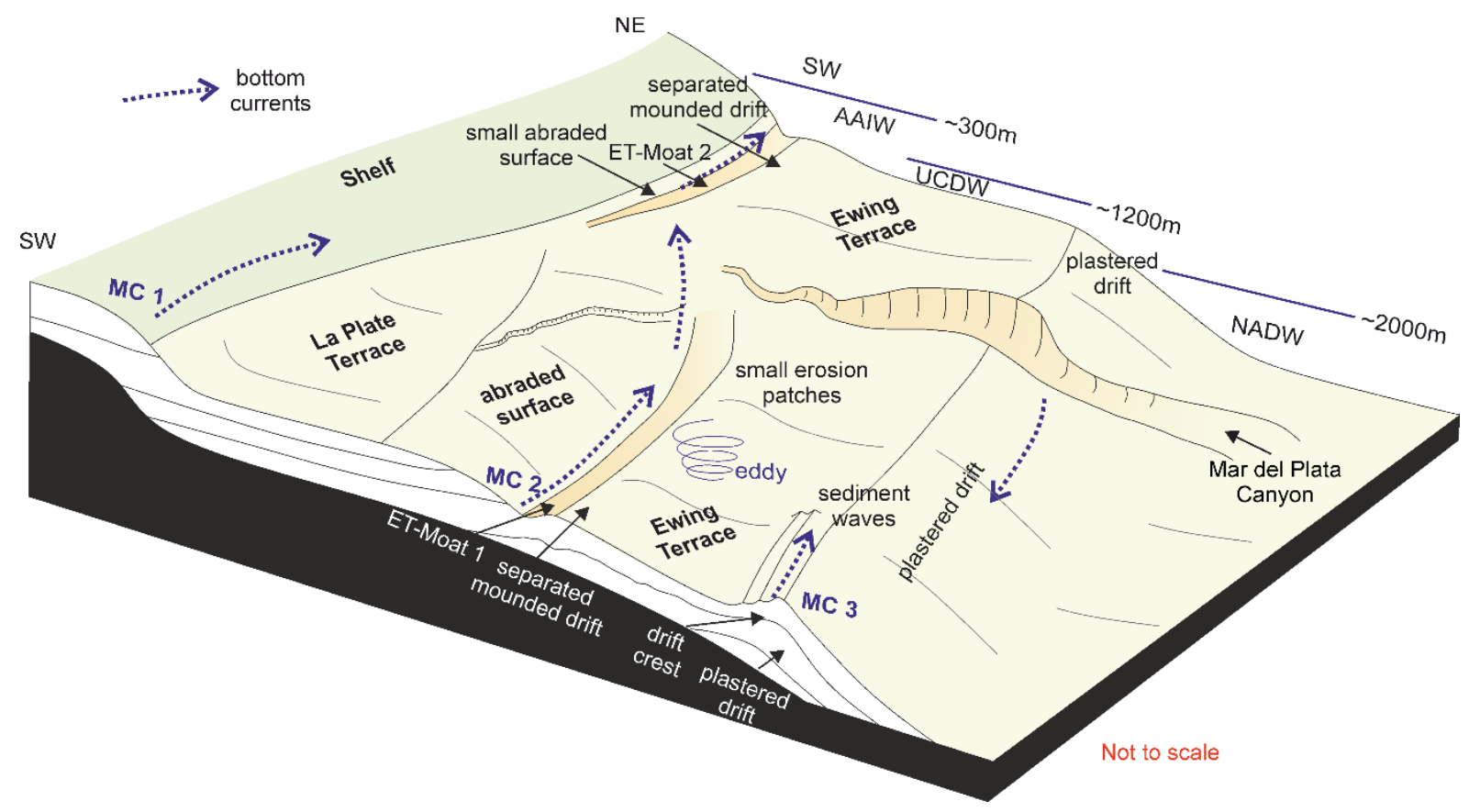

Fig. 14. Conceptual model of the main bottom currents and associated contouritic features in the study area. The approximate water mass interfaces in this region are indicated (after Preu et al., 2013; Kasten et al., 2019; Piola and Matano, 2019). MC: Malvinas Current, SW: Surface Water, AAIW: Antarctic Intermediate Water, UCDW: Upper Circumpolar Deep Water, NADW: North Atlantic Deep Water.

\subsection{Sediment origin and submarine transport}

The continental shelf and upper-middle slope of the northern Argentine margin are mainly dominated by sandy sediments (Fig. 12; Razik et al., 2015a and references therein). Loessoidal sands eroded from cliffs are one of the main sources for sandy deposits on the shelf, they are retransported by the Patagonian Current flowing northwards and are in part 
deposited on the outer shelf and upper slope offshore the Río de la Plata estuary (Gaiero et al., 2003; Razik et al., 2015a). Even though the aeolian dust supply from South America to the south Atlantic Ocean is very significant (Gaiero et al., 2003, Gaiero et al., 2007), aeolian dust $(5-20 \mu \mathrm{m})$ is mainly deposited in the deep part of the Argentine Basin (Sachs and Ellwood, 1988). In several morphological depressions gravel to cobble sized rocks are found (Fig. 12) and it was proposed that they have been transported by sea ice from the Antarctic Peninsula and Subantarctic islands (Bozzano et al., 2021). The primary origin of sediment deposits in the study area (upper and middle slope in the northern Argentine margin) was linked to a mountainous origin and igneous source rock lithology from the Andes, transported by the Colorado and Negro Rivers to the ocean (Razik et al., 2015a; Bozzano et al., 2011). In the modern system sediment from the rivers is mainly deposited at their deltas (Gaiero et al., 2003). However, during sea-level lowstands sediment from the Patagonian rivers reached directly the continental slope (e.g. Zárate and Blasi, 1993). The sediment is then transported northward by along-slope bottom currents (Malvinas Current) and is finally deposited in the study area forming the observed contourite depositional system. The sediment derived from the Río de La Plata is at present mainly transported northwards by longshore currents and does not reach our study area (Razik et al., 2015a). Occasionally, when the Brazil Current is very strong (Fig. 3C), sediment may also enter the study area from the north. However, the area is primarily controlled by the northward flowing along-slope bottom currents and shows generally a northward grain size fining due to the decreasing current speed. This trend continues beyond the study area on the Uruguayan margin (Franco-Fraguas et al., 2014).

Part of the sediment transported northwards along the Ewing Terrace may reach the head of the MdP Canyon. The general decrease in northward bottom current speed towards the MdP Canyon (Fig. 3, Fig. 7) would favour the accumulation of sediments at the canyon head that could be transported down canyon by turbidity currents, in a similar way as longshore currents feeding shelf-incised submarine canyons like the Monterrey Canyon (Paull et al., 2005) and the Cap Breton Canyon (Mazières et al., 2014). Voigt et al. (2013) and Warratz et al. (2019) reported the absence of turbidites during the Holocene and the presence of 
turbidites during deglacial and glacial periods, which have the same composition as the sediments from the Ewing Terrace (Warratz et al., 2019). This was previously linked to variability in the nepheloid layer depending on the current strength (Voigt et al., 2013, Voigt et al., 2016; Warratz et al., 2019). Since sandy sediment is transported mainly as bedload under the observed and modelled bottom-current velocities and is not part of the nepheloid layer, we propose that sediment transport associated with high velocity along-slope bottom current jets (here MC2) plays an important role in the sediment input to the MdP Canyon head and is then transported downslope by turbidity currents. The presence of only one major tributary to the MdP Canyon (Fig. 2; Krastel et al., 2011) and missing slope failure structures at the canyon walls (Warratz et al., 2019) also indicates a sediment input coming from the canyon head rather than from the southern lateral side of the canyon.

Some previous studies focused more on the variability of the latitude of the confluence zone and on the reconstruction of the strength of the Malvinas Current based on geological, geophysical data and oceanographic data (Lumpkin and Garzoli, 2011; Preu et al., 2012, Preu et al., 2013; Voigt et al., 2013, Voigt et al., 2016; Razik et al., 2015a; Artana et al., 2018, Artana et al., 2021b). It is important to consider that the mean latitude of the confluence zone is not the same at the sea surface and near the seafloor (Fig. 6). The reanalyses from Artana et al. (2021b) showed that the strength of the Malvinas Current has not changed over the period of 1993-2017. The location of the confluence zone is a result of the strengths of Brazil Current and Malvinas Current. Even though the strength of the Malvinas Current does not change (Artana et al., 2021a), a southward shift of the mean confluence zone of 0.6 to $0.9^{\circ}$ per decade was observed in recent times (1992-2007) (Lumpkin and Garzoli, 2011). Thus, the shift in the confluence might be more controlled by the Brazil Current. This southward trend of the confluence zone is expected to continue with the present global warming due to anthropogenic climate change (de Souza et al., 2019). This shift could possibly threaten the cold-water coral ecosystem on the Ewing Terrace (Hebbeln et al., 2016; Steinmann et al., 2020) and other benthic and pelagic species (Franco et al., 2020). 
The frequency of turbidity currents in the MdP Canyon is linked to the strength of the Malvinas Current. After the last glacial maximum, when the climate became generally warmer and sea level rose, the Malvinas Current became weaker on average (Preu et al., 2013; Voigt et al., 2013; Warratz et al., 2019). These weaker currents can only transport finer sediment and thus probably transported less sediment into the study area leading to a lower sedimentation rate and fewer turbidites in the MdP Canyon (Voigt et al., 2013, Voigt et al., 2016; Warratz et al., 2019). The described onset of sediment wave deposition on the Ewing Terrace possibly started in this less energetic environment (Fig. 11).

\section{Conclusions}

This study represents a step forward in understanding the sediment dynamics in proximity to the Mar del Plata (MdP) submarine Canyon at the northern Argentine margin by combining geophysical and sedimentological datasets (multibeam bathymetry, seismo-acoustic data and sediment cores) with oceanographic datasets and modelling (vessel-mounted ADCP measurements, CTD data and an ocean reanalysis). Overall, this study contributes to a better understanding of the formation of contourite depositional systems and can help future reconstructions of past ocean conditions based on sedimentary structures. The main conclusions can be summarized as follows:

- Measured and modelled current data show that in close proximity to the MdP Canyon the Malvinas Current dominates the sediment dynamics at the seafloor. We propose that sediment transport associated with high-velocity along-slope near-bottom current jets plays an important role in supplying sediments to the MdP Canyon head similarly to longshore currents feeding shelf-incised submarine canyons. The moat of the Ewing Terrace is possibly also a pathway for sediment transport to the MdP Canyon head.

- $\quad$ ADCP measurements together with the 25-year reanalysis of ocean currents show a northward velocity decrease of the northward-flowing waters. This decrease in speed leads to less erosion and the accumulation of finer sediment deposits north of the MdP Canyon, as observed in the surface sediment samples. 
- Modelling results indicate that near the seafloor the Malvinas Current splits into 3 branches (at $\sim 39^{\circ} S$ ). The shallowest branch (MC1) flows along the upper slope of the La Plata Terrace and continues flowing below the Brazil Current reaching $\sim 36^{\circ} \mathrm{S}$. MC2 flows along the abraded surface connecting the La Plata and Ewing Terrace. The offshore branch (MC3) flows at the basinward edge of the Ewing Terrace and drastically decreases in speed south of the MdP Canyon.

- The decrease in speed of branch MC3 reduces sediment transport capacity, which therefore allows deposition along its path and possibly leads to the formation of the observed drift crest. Downstream (northward) of the drift crest sediment waves with a parallel orientation to the flow direction are deposited.

- Instantaneous measured and modelled mean near-bottom currents are strong (up to $63 \mathrm{~cm} / \mathrm{s}$ at 150-200 $\mathrm{m}$ above the seafloor) where abraded surfaces and moats are present, and weak (lower than $30 \mathrm{~cm} / \mathrm{s}$ ) on the La Plata Terrace and the Ewing Terrace. The strong bottom currents generate the moats located at the landward slope of the Ewing Terrace that are very sandy and even gravelly. In the moats, an intensification in flow velocity was measured and an up-slope migration observed. We suggest that contourite terraces may have been initiated by the action of two water masses and their interphase trough time, being the erosion on the slope generated by the (paleo) Malvinas Current that would progressively cut the slope landwards, widening the contourite terrace with time.

- The divergence of isobaths at the terraces possibly explains the measured and modelled weaker near-bottom currents on the La Plata Terrace and the Ewing Terrace. Together with the sloping morphology of the Ewing Terrace this can lead to flow instabilities near the seafloor. We suggest that this effect leads to local cyclonic eddies near the seafloor, which have also been measured and modelled. We propose that these eddies are transient and can cause local erosion only during energetic periods. The alternation between sediment deposition and erosion may also explain the absence 
of a clear large-scale erosional surface and the presence of several small erosional surfaces at the Ewing Terrace.

\section{Data Availability}

The ADCP data, surface grain size analyses, Parasound Data and Seismic Data used in this article are available at PANGAEA database (Wilckens et al. (2021) https://doi.org/10.1594/PANGAEA.931130). Modelled data is freely available from the Copernicus Marine Environment Monitoring Service (CMEMS, http://marine.copernicus.eu/).

\section{Declaration of Competing interest}

The authors declare that they have no known competing financial interests or personal relationships that could have appeared to influence the work reported in this paper.

\section{Acknowledgements:}

We thank the captains, crews and onboard scientific teams for their support during $R / V$ SONNE cruise SO260 in 2018, R/V Meteor cruise M78/3 in 2009 and R/V Meteor cruise M49/2 in 2001. We appreciate the help of K. Zonneveld and K.-H. Baumann for processing the CTD data during the SO260 cruise. We thank Brit Kockisch for her support during the collection and analysis of sediment samples. For funding of the cruise SO260 we acknowledge the DFG Research Centre/Cluster of Excellence 'The Ocean in the Earth System' (MARUM - Center for Marine Environmental Sciences at the University of Bremen). For additional funding we thank the Helmholtz Association (Alfred Wegener Institute Helmholtz Centre for Polar and Marine Research, Bremerhaven). The sediment sample material was provided by the GeoB Core Repository at the MARUM - Center for Marine Environmental Sciences, University of Bremen, Germany. The project was funded by the University of Bremen and supported by the GLOMAR - Bremen International Graduate School for Marine Sciences. This work has been done in collaboration with "The Drifters Research Group" at Royal Holloway University of 
London (RHUL). We thank the two anonymous reviewers and the guest editor A. Wåhlin for their comments that greatly improved our manuscript.

\section{References}

Artana, C., Lellouche, J.M., Park, Y.H., Garric, G., Koenig, Z., Sennéchael, N., Ferrari, R., Piola, A.R., Saraceno, M., Provost, C., 2018. Fronts of the malvinas current system: surface and subsurface expressions revealed by satellite altimetry, argo floats, and mercator operational model outputs. J. Geophys. Res. Oceans 123, 5261-5285.

Artana, C., Provost, C., Lellouche, J.M., Rio, M.H., Ferrari, R., Sennéchael, N., 2019. The Malvinas current at the confluence with the Brazil current: inferences from 25 years of Mercator Ocean reanalysis. J. Geophys. Res. Oceans 124 (10), 7178-7200.

Artana, C., Provost, C., Poli, L., Ferrari, R., Lellouche, J.-M., 2021a. Revisiting the Malvinas Current upper circulation and water masses using a high-resolution ocean reanalysis. J. Geophys. Res. Oceans 126 (6) e2021JC017271.

Artana, C., Ferrari, R., Bricaud, C., Lellouche, J.-M., Garric, G., Sennéchael, N., Lee, J.-H., Park, Y.-H., Provost, C., 2021b. Twenty-five years of Mercator Ocean reanalysis GLORYS12 at Drake Passage: velocity assessment and total volume transport. Adv. Space Res. 68 (2), 447-466.

Betzler, C., Lüdmann, T., Hübscher, C., Fürstenau, J., 2013. Current and sea-level signals in periplatform ooze (Neogene, Maldives, Indian Ocean). Sediment. Geol. 290, 126-137.

Blumsack, S., Weatherly, G., 1989. Observations of the nearby flow and a model for the growth of mudwaves. Deep Sea Res. A Oceanogr. Res. Pap. 36, 1327-1339.

Bozzano, G., Cerredo, M.E., Remesal, M., Steinmann, L., Hanebuth, T.J.J., Schwenk, T., Baqués, M., Hebbeln, D., Spoltore, D., Silvestri, O., Acevedo, R.D., Spiess, V., Violante, R.A., Kasten, S., 2021. Dropstones in the Mar del Plata Canyon Area (SW Atlantic): evidence for provenance, transport, distribution, and oceanographic implications. Geochem. Geophys. Geosyst. 22(1) e2020GC009333.

Bozzano, G., Violante, R.A., Cerredo, M.E., 2011. Middle slope contourite deposits and associated sedimentary facies off NE Argentina. Geo-Mar. Lett. 31, 495-507.

Brackenridge, R.E., Nicholson, U., Sapiie, B., Stow, D., Tappin, D.R., 2020. Indonesian Throughflow as a preconditioning mechanism for submarine landslides in the Makassar Strait. Geol. Soc. Lond., Spec. Publ. 500, 195-217. 
Carranza, A., Recio, A.M., Kitahara, M., Scarabino, F., Ortega, L., López, G., Franco- Fraguas, P., De Mello, C., Acosta, J., Fontan, A., 2012. Deep-water coral reefs from the Uruguayan outer shelf and slope. Mar. Biodivers. 42, 411-414.

Chen, H., Zhang, W., Xie, X., Ren, J., 2019. Sediment dynamics driven by contour currents and mesoscale eddies along continental slope: a case study of the northern South China Sea. Mar. Geol. 409, 48-66.

de Souza, M.M., Mathis, M., Pohlmann, T., 2019. Driving mechanisms of the variability and long-term trend of the Brazil-Malvinas confluence during the 21st century. Climate Dynamics 53 (9-10), 6453-6468.

Droghei, R., Falcini, F., Casalbore, D., Martorelli, E., Mosetti, R., Sannino, G., Santoleri, R., Chiocci, F., 2016. The role of Internal Solitary Waves on deep-water sedimentary processes: the case of up-slope migrating sediment waves off the Messina Strait. Sci. Rep. $6,36376$.

Ercilla, G., Juan, C., Hernandez-Molina, F.J., Bruno, M., Estrada, F., Alonso, B., Casas, D., lí Farran, M., Llave, E., Garcia, M., 2016. Significance of bottom currents in deep-sea morphodynamics: an example from the Alboran Sea. Mar. Geol. 378, 157-170.

Falcini, F., Jerolmack, D.J., 2010. A potential vorticity theory for the formation of elongate channels in river deltas and lakes. J. Geophys. Res. Earth Surf. 115.

Faugères, J.-C., Stow, D.A., Imbert, P., Viana, A., 1999. Seismic features diagnostic of contourite drifts. Mar. Geol. 162, 1-38.

Flood, R.D., 1988. A lee wave model for deep-sea mudwave activity. Deep Sea Res. A Oceanogr. Res. Pap. 35, 973-983.

Franco, B.C., Defeo, O., Piola, A.R., Barreiro, M., Yang, H., Ortega, L., Gianelli, I., Castello, J.P., Vera, C.S., Buratti, C., Pájaro, M., Pezzi, L.P., Möller, O.O., 2020. Climate change impacts on fisheries in the southwest South Atlantic Ocean: a review. Clim. Chang. 1-19.

Franco-Fraguas, P., Burone, L., Mahiques, M., Ortega, L., Urien, C., Muñoz, A., López, G., Marin, Y., Carranza, A., Lahuerta, N., 2014. Hydrodynamic and geomorphological controls on surface sedimentation at the subtropical shelf front/Brazil-Malvinas confluence transition off Uruguay (southwestern Atlantic continental margin). Mar. Geol. 349, 24-36.

Franco-Fraguas, P., Burone, L., Mahiques, M., Ortega, L., Carranza, A., 2016. Modern sedimentary dynamics in the Southwestern Atlantic Contouritic Depositional System: new insights from the Uruguayan margin based on a geochemical approach. Mar. Geol. 376, 15-25.

Franke, D., Neben, S., Ladage, S., Schreckenberger, B., Hinz, K., 2007. Margin segmentation and volcano-tectonic architecture along the volcanic margin off Argentina/Uruguay, South Atlantic. Mar. Geol. 244, 46-67. 
Frenz, M., Höppner, R., Stuut, J.-B., Wagner, T., Henrich, R., 2003a. Surface sediment bulk geochemistry and grain-size composition related to the oceanic circulation along the South American continental margin in the Southwest Atlantic. In: The South Atlantic in the Late Quaternary. Springer, pp. 347-373.

Frenz, Michael, Höppner, René, Stuut, Jan-Berend W., Wagner, Thomas, Henrich, Rüdiger, 2003b. Terrigenous silt grain-size distributions in the SW Atlantic. PANGAEA. https://doi.org/10.1594/PANGAEA.95396 [dataset] In supplement to: Frenz, M et al. (2003): Surface Sediment Bulk Geochemistry and Grain-Size Composition Related to the Oceanic Circulation along the South American Continental Margin in the Southwest Atlantic. In: Wefer, G; Mulitza, S \& Ratmeyer, V (eds.), The South Atlantic in the Late Quaternary: Reconstruction of Material Budgets and Current Systems, Springer, Berlin, Heidelberg, New York, 347-373.

Gaiero, D.M., Probst, J.-L., Depetris, P.J., Bidart, S.M., Leleyter, L., 2003. Iron and other transition metals in Patagonian riverborne and windborne materials: geochemical control and transport to the southern South Atlantic Ocean. Geochim. Cosmochim. Acta 67, 36033623.

Gaiero, D.M., Brunet, F., Probst, J.-L., Depetris, P.J., 2007. A uniform isotopic and chemical signature of dust exported from Patagonia: rock sources and occurrence in southern environments. Chem. Geol. 238, 107-120.

GEBCO, Compilation-Group, 2020. GEBCO 2020 Grid.

Giberto, D., Bremec, C., Acha, E.M., Mianzan, H., 2004. Large-scale spatial patterns of benthic assemblages in the SW Atlantic: the Rı de la Plata estuary and adjacent shelf waters. Estuar. Coast. Shelf Sci. 61, 1-13.

Gordon, A.L., Greengrove, C.L., 1986. Geostrophic circulation of the Brazil-Falkland confluence. Deep Sea Res. A Oceanogr. Res. Pap. 33, 573-585.

Grant, J., Schreiber, R., 1990. Modern swathe sounding and sub-bottom profiling technology for research applications: the Atlas Hydrosweep and Parasound systems. In: Marine Geological Surveying and Sampling. Springer, pp. 9-19.

Hand, B.M., 1974. Supercritical flow in density currents. J. Sediment. Res. 44, 637-648.

Hebbeln, D., Van Rooij, D., Wienberg, C., 2016. Good neighbours shaped by vigorous currents: cold-water coral mounds and contourites in the North Atlantic. Mar. Geol. 378, 171-185.

Heezen, B.C., 1959. Dynamic processes of abyssal sedimentation: erosion, transportation, and redeposition on the deep-sea floor. Geophys. J. Int. 2, 142-163.

Heezen, B.C., Hollister, C., 1964. Deep-sea current evidence from abyssal sediments. Mar. Geol. 1, 141-174. 
Hernández-Molina, F.J., Paterlini, M., Violante, R., Marshall, P., de Isasi, M., Somoza, L., Rebesco, M., 2009. Contourite depositional system on the Argentine Slope: an exceptional record of the influence of Antarctic water masses. Geology 37, 507-510.

Hernández-Molina, F.J., Soto, M., Piola, A.R., Tomasini, J., Preu, B., Thompson, P., Badalini, G., Creaser, A., Violante, R.A., Morales, E., Paterlini, M., De Santa Anab, H., 2016a. A contourite depositional system along the Uruguayan continental margin: sedimentary, oceanographic and paleoceanographic implications. Mar. Geol. 378, 333-349.

Hernández-Molina, F.J., Wåhlin, A., Bruno, M., Ercilla, G., Llave, E., Serra, N., Rosón, G., Puig, P., Rebesco, M., Van Rooij, D., 2016b. Oceanographic processes and morphosedimentary products along the lberian margins: a new multidisciplinary approach. Mar. Geol. 378, 127-156.

Hernández-Molina, F.J., Campbell, S., Badalini, G., Thompson, P., Walker, R., Soto, M., Conti, B., Preu, B., Thieblemont, A., Hyslop, L., 2018. Large bedforms on contourite terraces: Sedimentary and conceptual implications. Geology 46, 27-30.

Hinz, K., Neben, S., Schreckenberger, B., Roeser, H., Block, M., De Souza, K.G., Meyer, H., 1999. The Argentine continental margin north of $48 \mathrm{~S}$ : sedimentary successions, volcanic activity during breakup. Mar. Pet. Geol. 16, 1-25.

Hopfauf, V., Spieß, V., 2001. A three-dimensional theory for the development and migration of deep sea sedimentary waves. Deep-Sea Res. I Oceanogr. Res. Pap. 48, 2497-2519.

Inman, D.L., 1949. Sorting of sediments in the light of fluid mechanics. J. Sediment. Res. 19, $51-70$.

Jackson, C.R., Da Silva, J.C., Jeans, G., 2012. The generation of nonlinear internal waves. Oceanography 25, 108-123.

Kane, I.A., Clare, M.A., Miramontes, E., Wogelius, R., Rothwell, J.J., Garreau, P., Pohl, F., 2020. Seafloor microplastic hotspots controlled by deep-sea circulation. Science 368 , $1140-1145$.

Kasten, S., Schwenk, T., Aromokeye, D.A., Baques, M., Baumann, K.-H., Bergenthal, M., Bösche, J., Bozzano, G., Brune, R., Bülten, J., Chiessi, C.M., Coffinet, S., Crivellari, S., Garcia Chapori, N., Gonzalez, L., Hanebuth, T.J.J., Hilgenfeldt, C., Hüttich, D., Jones, C.K., Klann, M., Klar, S., Klein, T., Kockisch, B., Köster, M., Lantzsch, H., Linowski, E., Long, J.H., Melcher, A.-C., Ogunleye, O.J., Pereyra, N., Rehage, R., Riedinger, N., Rosiak, U., Schmidt, W., Schnakenberg, A., Spieß, V., Steinmann, L., Thieblemont, A., Volz, J., Warnke, F., Warratz, G., Wenau, S., Zonneveld, K.A.F., 2019. Dynamics of sedimentation processes and their impact on biogeochemical reactions on the continental slope off Argentina and Uruguay (MARUM). In: Cruise No. SO260/Leg 1 \& Leg 2, Leg 1: January 12-January 30, 2018, Buenos Aires (Argentina)-Montevideo (Uruguay), Leg 2: February 2- 
February, 14, 2018, Montevideo (Uruguay)-Buenos Aires (Argentina), DosProBio, SonneBerichte.

Krastel, S., Wefer, G., 2012. Report and preliminary results of RV METEOR Cruise M78/ 3. In: Sediment Transport off Uruguay and Argentina: From the Shelf to the Deep Sea; 19.05. 2009-06.07, 2009, Montevideo (Uruguay)-Montevideo (Uruguay). Meteor-Berichte.

Krastel, S., Wefer, G., Hanebuth, T.J., Antobreh, A.A., Freudenthal, T., Preu, B., Schwenk, T., Strasser, M., Violante, R., Winkelmann, D., 2011. Sediment dynamics and geohazards off Uruguay and the de la Plata River region (northern Argentina and Uruguay). Geo-Mar. Lett. $31,271-283$.

Lellouche, J.-M., Greiner, E., Le Galloudec, O., Garric, G., Regnier, C., Drevillon, M., Benkiran, M., Testut, C.-E., Bourdalle-Badie, R., Gasparin, F., Hernandez, O., Levier, B., Drillet, Y., Remy, E., Le Traon, P.-Y., 2018. Recent updates on the Copernicus Marine Service global ocean monitoring and forecasting real-time $1 / 12 \circ$ high resolution system. Ocean Sci. Discuss. 14, 1093-1126.

Llave, E., Hernández-Molina, F.J., García, M., Ercilla, G., Roque, C., Juan, C., Mena, A., Preu, B., Van Rooij, D., Rebesco, M., 2020. Contourites along the Iberian continental margins: conceptual and economic implications. Geol. Soc. Lond., Spec. Publ. 476, 403-436.

Lumpkin, R., Garzoli, S., 2011. Interannual to decadal changes in the western South Atlantic's surface circulation. J. Geophys. Res. Oceans 116.

Maamaatuaiahutapu, K., Garçon, V.C., Provost, C., Boulahdid, M., Bianchi, A.A., 1994. Spring and winter water mass composition in the Brazil-Malvinas Confluence. J. Mar. Res. 52, 397-426.

Magalhaes, J., da Silva, J., 2017. Close Internal waves along the Malvinas Current: evidence of transcritical generation in satellite imagery. Oceanography 30, 110-119.

Mazières, A., Gillet, H., Castelle, B., Mulder, T., Guyot, C., Garlan, T., Mallet, C., 2014. Highresolution morphobathymetric analysis and evolution of Capbreton submarine canyon head (Southeast Bay of Biscay_French Atlantic Coast) over the last decade using descriptive and numerical modeling. Mar. Geol. 351, 1-12.

McCave, I.N., 2017. Formation of sediment waves by turbidity currents and geostrophic flows: a discussion. Mar. Geol. 390, 89-93.

Miramontes, E., Cattaneo, A., Jouet, G., Thereau, E., Thomas, Y., Rovere, M., Cauquil, E., Trincardi, F., 2016. The Pianosa contourite depositional system (northern Tyrrhenian Sea): drift morphology and Plio-Quaternary stratigraphic evolution. Mar. Geol. 378, 20-42.

Miramontes, E., Garziglia, S., Sultan, N., Jouet, G., Cattaneo, A., 2018. Morphological control of slope instability in contourites: a geotechnical approach. Landslides 15, 1085-1095. 
Miramontes, E., Garreau, P., Caillaud, M., Jouet, G., Pellen, R., Hernández-Molina, F.J., Clare, M.A., Cattaneo, A., 2019. Contourite distribution and bottom currents in the NW Mediterranean Sea: coupling seafloor geomorphology and hydrodynamic modelling. Geomorphology 333, 43-60.

Miramontes, E., Jouet, G., Thereau, E., Bruno, M., Penven, P., Guerin, C., Le Roy, P., Droz, L., Jorry, S.J., Hernández-Molina, F.J., 2020. The impact of internal waves on upper continental slopes: insights from the Mozambican margin (Southwest Indian Ocean). Earth Surf. Process. Landf. 45, 1469-1482.

Miramontes, E., Thiéblemont, A., Babonneau, N., Penven, P., Raisson, F., Droz, L., Jorry, S.J., Fierens, R., Counts, J.W., Wilckens, H., Cattaneo, A., Jouet, G., 2021. Contourite and mixed turbidite-contourite systems in the Mozambique Channel (SW Indian Ocean): link between geometry, sediment characteristics and modelled bottom currents. Mar. Geol. 106502.

Muñoz, A., Cristobo, J., Rios, P., Druet, M., Polonio, V., Uchupi, E., Acosta, J., Group, A, 2012. Sediment drifts and cold-water coral reefs in the Patagonian upper and middle continental slope. Mar. Pet. Geol. 36, 70-82.

Paull, C.K., Mitts, P., Ussler III, W., Keaten, R., Greene, H.G., 2005. Trail of sand in upper Monterey Canyon: offshore California. Geol. Soc. Am. Bull. 117, 1134-1145.

Piola, A.R., Matano, R.P., 2019. Ocean currents: Atlantic Western Boundary - Brazil Current/Falkland (Malvinas) Current. In: Cochran, J.K., Bokuniewicz, H., Yager, P. (Eds.), Encyclopedia of Ocean Sciences, 3rd ed.

Piola, A.R., Franco, B.C., Palma, E.D., Saraceno, M., 2013. Multiple jets in the Malvinas Current. J. Geophys. Res. Oceans 118, 2107-2117.

Piola, A.R., Palma, E.D., Bianchi, A.A., Castro, B.M., Dottori, M., Guerrero, R.A., Marrari, M., Matano, R.P., Möller, O.O., Saraceno, M., 2018. Physical oceanography of the SW Atlantic Shelf: a review. In: Plankton Ecology of the Southwestern Atlantic. Springer, pp. 37-56.

Preu, B., Schwenk, T., Hernández-Molina, F.J., Violante, R., Paterlini, M., Krastel, S., Tomasini, J., Spieß, V., 2012. Sedimentary growth pattern on the northern Argentine slope: the impact of North Atlantic Deep Water on southern hemisphere slope architecture. Mar. Geol. 329-331, 113-125.

Preu, B., Hernández-Molina, F.J., Violante, R., Piola, A.R., Paterlini, C.M., Schwenk, T., Voigt, I., Krastel, S., Spiess, V., 2013. Morphosedimentary and hydrographic features of the northern Argentine margin: the interplay between erosive, depositional and gravitational processes and its conceptual implications. Deep-Sea Res. I Oceanogr. Res. Pap. 75, 157174. 
Provost, C., Gana, S., Garçon, V., Maamaatuaiahutapu, K., England, M., 1995. Hydrographic conditions in the Brazil-Malvinas Confluence during austral summer 1990. J. Geophys. Res. Oceans 100, 10655-10678.

Razik, S., Govin, A., Chiessi, C.M., von Dobeneck, T., 2015a. Depositional provinces, dispersal, and origin of terrigenous sediments along the SE South American continental margin. Mar. Geol. 363, 261-272.

Razik, Sebastian, Govin, Aline, Chiessi, Cristiano Mazur, von Dobeneck, Tilo, 2015b. (Fig. 3) Grain-size distributions of the terrigenous sediment fraction from surface sediment samples along the continental margin between East Brazil and Patagonia. PANGAEA. https://doi.org/10.1594/PANGAEA.843433 [dataset] In supplement to: Razik, S et al. (2015): Depositional provinces, dispersal, and origin of terrigenous sediments along the SE South American continental margin. Marine Geology, 363, 261-272, doi:10.1016/j.margeo.2015.03.001.

Rebesco, M., Camerlenghi, A., 2008. Contourites. Elsevier.

Rebesco, M., Hernández-Molina, F.J., Van Rooij, D., Wåhlin, A., 2014. Contourites and associated sediments controlled by deep-water circulation processes: state-of-the-art and future considerations. Mar. Geol. 352, 111-154.

Reeder, D.B., Ma, B.B., Yang, Y.J., 2011. Very large subaqueous sand dunes on the upper continental slope in the South China Sea generated by episodic, shoaling deep-water internal solitary waves. Mar. Geol. 279, 12-18.

Reiche, S., Hübscher, C., Brenner, S., Betzler, C., Hall, J.K., 2018. The role of internal waves in the late Quaternary evolution of the Israeli continental slope. Mar. Geol. 406, 177-192.

Reid, J.L., Nowlin, W.D., Patzert, W.C., 1977. On the characteristics and circulation of the southwestern Atlantic Ocean. J. Phys. Oceanogr. 7, 62-91.

Ribó, M., Puig, P., Muñoz, A., lacono, C.L., Masqué, P., Palanques, A., Acosta, J., Guillén, J., Ballesteros, M.G., 2016. Morphobathymetric analysis of the large fine-grained sediment waves over the Gulf of Valencia continental slope (NW Mediterranean). Geomorphology 253, 22-37.

Roberts, J.M., Wheeler, A.J., Freiwald, A., 2006. Reefs of the deep: the biology and geology of cold-water coral ecosystems. Science 312, 543-547.

Sachs, S.D., Ellwood, B.B., 1988. Controls on magnetic grain-size variations and concentration in the Argentine Basin, South Atlantic Ocean. Oceanograph. Res. Paper. 35 (6), 929-942.

Schlichting, H., 1962. Boundary Layer Theory, 6th ed. McGraw-Hill, New York. 744 pp.

Schlichting, H., Gersten, K., 2016. Boundary-Layer Theory. Springer. 
Soulsby, R., Whitehouse, R., 1997. Threshold of sediment motion in coastal environments. In: Pacific Coasts and Ports' 97: Proceedings of the 13th Australasian Coastal and Ocean Engineering Conference and the 6th Australasian Port and Harbour Conference; Volume 1. Centre for Advanced Engineering, University of Canterbury, p. 145.

Spieß, V., Albrecht, N., Bickert, T., Breitzke, M., Brüning, M., Dreyzehner, A., Groß, U., Krüger, D., von Lom-Keil, H., Möller, H., 2002. ODP Südatlantik 2001 Part 2. Meteor-Berichte 2, 1. Steinmann, L., Baques, M., Wenau, S., Schwenk, T., Spiess, V., Piola, A.R., Bozzano, G., Violante, R., Kasten, S., 2020. Discovery of a giant cold-water coral mound province along the northern Argentine margin and its link to the regional Contourite Depositional System and oceanographic setting. Mar. Geol. 427, 106223.

Stow, D.A., Faugères, J.-C., Howe, J.A., Pudsey, C.J., Viana, A.R., 2002a. Bottom currents, contourites and deep-sea sediment drifts: current state-of-the-art. Geol. Soc. Lond. Mem. 22, 7-20.

Stow, D.A.W., Pudsey, C.J., Howe, J.A., Faugeres, J.-C., Viana, A., 2002b. In: Deep-Water Contourite Systems: Modern Drifts and AncientSeries, Seismic and Sedimentary Characteristics. Geological Society, London, Memoirs, p. 466.

Stow, D.A., Hernández-Molina, F.J., Llave, E., Sayago-Gil, M., Díaz del Río, V., Branson, A., 2009. Bedform-velocity matrix: the estimation of bottom current velocity from bedform observations. Geology 37, 327-330.

Surlyk, F., Lykke-Andersen, H., 2007. Contourite drifts, moats and channels in the Upper Cretaceous chalk of the Danish Basin. Sedimentology 54, 405-422.

Thiéblemont, A., Hernández-Molina, F.J., Miramontes, E., Raisson, F., Penven, P., 2019. Contourite depositional systems along the Mozambique channel: the interplay between bottom currents and sedimentary processes. Deep-Sea Res. I Oceanogr. Res. Pap. 147, 79-99.

Thran, A.C., Dutkiewicz, A., Spence, P., Müller, R.D., 2018. Controls on the global distribution of contourite drifts: insights from an eddy-resolving ocean model. Earth Planet. Sci. Lett. 489, 228-240.

Urien, C.M., Ewing, M., 1974. Recent sediments and environment of southern Brazil, Uruguay, Buenos Aires, and Rio Negro continental shelf. In: The Geology of Continental Margins. Springer, pp. 157-177.

Valla, D., Piola, A.R., Meinen, C.S., Campos, E., 2018. Strong mixing and recirculation in the northwestern Argentine Basin. J. Geophys. Res. Oceans 123, 4624-4648.

Van Haren, H., Gostiaux, L., 2011. Large internal waves advection in very weakly stratified deep Mediterranean waters. Geophys. Res. Lett. 38. 
Vivier, F., Provost, C., 1999. Direct velocity measurements in the Malvinas Current. J. Geophys. Res. Oceans 104, 21083-21103.

Voigt, I., Henrich, R., Preu, B., Piola, A.R., Hanebuth, T.J., Schwenk, T., Chiessi, C.M., 2013. A submarine canyon as a climate archive-interaction of the Antarctic Intermediate Water with the Mar del Plata Canyon (Southwest Atlantic). Mar. Geol. 341, 46-57.

Voigt, I., Chiessi, C.M., Piola, A.R., Henrich, R., 2016. Holocene changes in Antarctic Intermediate Water flow strength in the Southwest Atlantic. Palaeogeogr. Palaeoclimatol. Palaeoecol. 463, 60-67.

Warratz, G., Henrich, R., Voigt, I., Chiessi, C.M., Kuhn, G., Lantzsch, H., 2017. Deglacial changes in the strength of deep southern component water and sediment supply at the Argentine continental margin. Paleoceanography 32, 796-812.

Warratz, G., Schwenk, T., Voigt, I., Bozzano, G., Henrich, R., Violante, R., Lantzsch, H., 2019. Interaction of a deep-sea current with a blind submarine canyon (Mar del Plata Canyon, Argentina). Mar. Geol. 417, 106002.

Wilckens, Henriette, Miramontes, Elda, Schwenk, Tilmann, Artana, Camila, Zhang, Wenyan, Piola, Alberto R., Baqués, Michele, Hernandéz-Molina, Francisco Javier, Felgendreher, Meret, Spieß, Volkhard, Kasten, Sabine, 2021. Acoustic Data (Vessel-Mounted ADCP, Parasound and Multi-Channel Seismic Reflection Profiles) and Grain-Size Analyses of Surface Sediment Samples from off Northern Argentina and Uruguay. https://doi.org/10.1594/PANGAEA.931130.

Yin, S., Hernández-Molina, F.J., Zhang, W., Li, J., Wang, L., Ding, W., Ding, W., 2019. The influence of oceanographic processes on contourite features: a multidisciplinary study of the northern South China Sea. Mar. Geol. 415, 105967.

Zárate, M., Blasi, A., 1993. Late Pleistocene-Holocene eolian deposits of the southern Buenos Aires Province, Argentina: a preliminary model. Quat. Int. 17, 15-20.

Zhang, W., Hanebuth, T.J., Stöber, U., 2016. Short-term sediment dynamics on a meso-scale contourite drift (off NW Iberia): impacts of multi-scale oceanographic processes deduced from the analysis of mooring data and numerical modelling. Mar. Geol. 378, 81-100. 


\section{Supplementary material}

\section{S1 Bathymetry of the used Model}

For the analyses of model bottom currents, the underlying bathymetry plays a vital part because the currents interact with the seafloor morphology. There are generally no major differences between the ETOPO Bathymetry used for the Model (Fig. S1A) and the GEBCO Bathymetry combined with the 100-m grid measured with a Multibeam Echosounder (MBES) used for the geomorphological analysis (Fig. S1B). The comparison of the isobaths calculated from the different grids shows generally the same structure. On the shelf, both grids are similar, and in the study area (450 to $1400 \mathrm{~m}$ water depth), the differences are only minor. Because of the lower resolution of the ETOPO grid, the steep slopes cannot be resolved with the same details and the canyons are slightly wider (Fig. S1C).
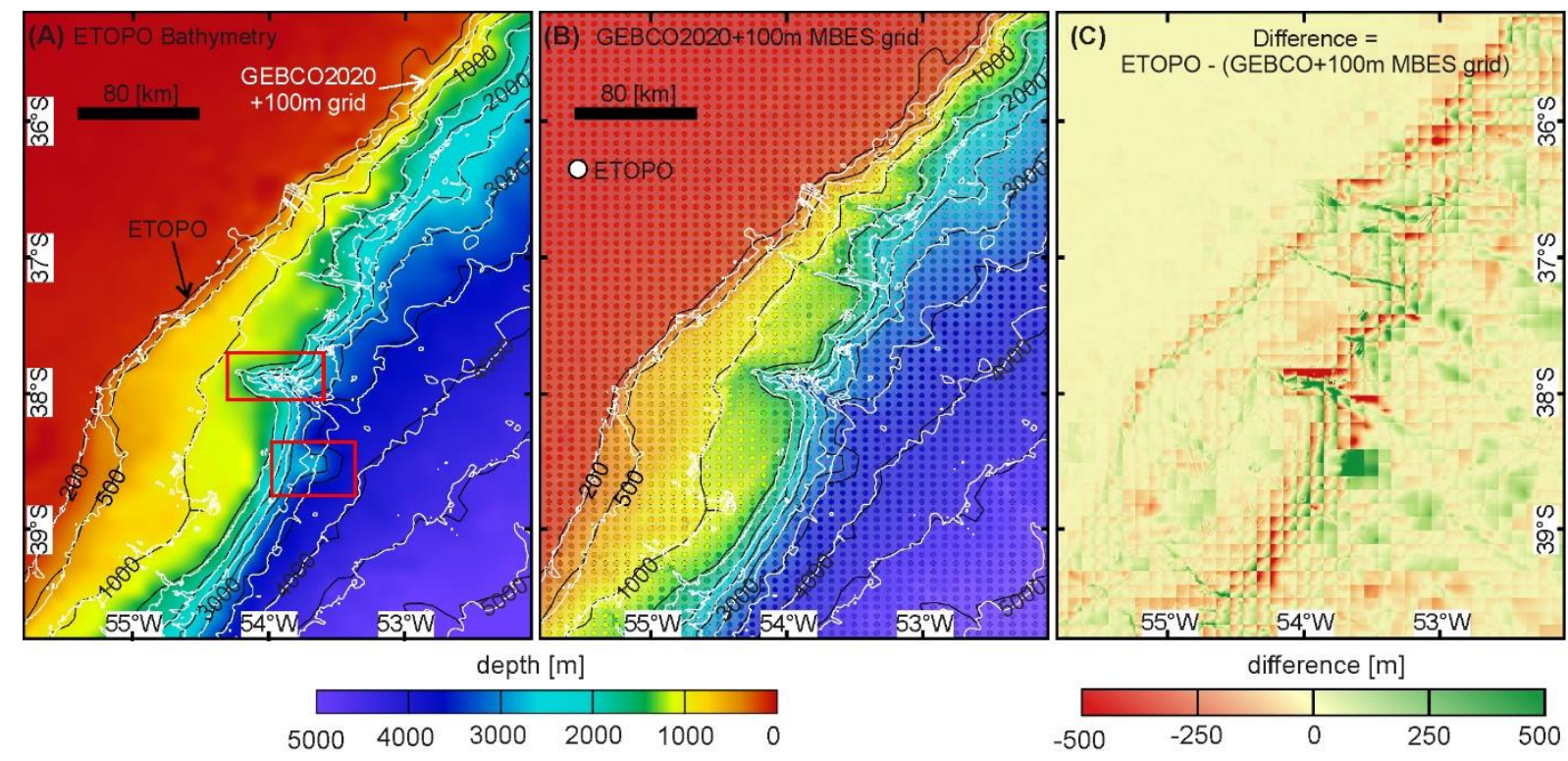

Fig. S1: (A) ETOPO Bathymetry used for the Model. The red boxes indicate differences between isobaths calculated from ETOPO Bathymetry and of GEBCO Bathymetry combined with the 100-m grid measured with a Multibeam Echosounder (MBES). (B) Comparison between the GEBCO Bathymetry combined with the $100 \mathrm{~m}$ grid and ETOPO Bathymetry (coloured dots). (C) Difference between the ETOPO Bathymetry and the GEBCO Bathymetry combined with the 100-m grid. 


\section{S2 Sediment samples}

Table S1: List and description of surface sediment samples used in this study: Multicorer (MUC), Giant Box Corer (GBC), Grab Sampler (GS), Gravity Corer (GC) and Sea floor drill rig (MeBo).

\begin{tabular}{|c|c|c|c|c|}
\hline GeoB \# & Long & Lat & Device & Sediment description \\
\hline GeoB13868-1 & -53.72 & -37.41 & MeBo & Very coarse silty very fine sand \\
\hline GeoB13844-4 & -53.73 & -37.42 & MeBo & Very fine sandy very coarse silt \\
\hline GeoB13845-11 & -55.12 & -38.17 & MeBo & Very fine sandy coarse silt, coral fragments \\
\hline GeoB13845-8 & -55.12 & -38.17 & MeBo & Very coarse silty very fine sand, coral fragments \\
\hline GeoB22701-2 & -54.18 & -37.82 & GBC & Very coarse silty very fine sand \\
\hline GeoB22702-2 & -54.17 & -37.81 & MUC & Coarse silty very fine sand \\
\hline GeoB22706-1 & -53.76 & -37.95 & MUC & Very fine sandy coarse silt \\
\hline GeoB22707-2 & -53.80 & -37.91 & MUC & Very fine sandy coarse silt \\
\hline GeoB22708-3 & -53.95 & -39.31 & MUC & Very fine sandy coarse silt \\
\hline GeoB22709-1 & -53.97 & -39.30 & GC & Very fine sandy coarse silt \\
\hline GeoB22711-1 & -54.48 & -38.33 & MUC & Coarse silty fine sand \\
\hline GeoB22712-3 & -54.49 & -38.33 & GBC & Coarse silty fine sand, cobbles, coral fragments \\
\hline GeoB22713-1 & -54.35 & -38.59 & MUC & Coarse silty very fine sand \\
\hline GeoB22714-1 & -54.38 & -38.63 & GC & Very coarse silty very fine sand \\
\hline GeoB22715-1 & -54.53 & -38.32 & GBC & Very coarse silty very fine sand, coral fragments \\
\hline GeoB22718-1 & -54.30 & -37.88 & GS & Very coarse silty medium sand \\
\hline GeoB22720-1 & -54.05 & -37.72 & GS & Very coarse silty very fine sand \\
\hline GeoB22721-1 & -53.98 & -37.56 & MUC & Very fine sandy very coarse silt \\
\hline GeoB22722-3 & -54.02 & -37.54 & MUC & Very fine sandy coarse silt \\
\hline GeoB22723-2 & -53.96 & -37.70 & MUC & Very coarse silty very fine sand \\
\hline GeoB22725-1 & -54.06 & -38.34 & MUC & Very coarse silty very fine sand \\
\hline GeoB22726-2 & -54.37 & -38.72 & GS & Very coarse silty very fine sand \\
\hline GeoB22727-1 & -54.39 & -38.69 & GS & Coarse silty fine sand \\
\hline GeoB22728-3 & -54.35 & -37.78 & GS & Very fine sandy medium silt \\
\hline GeoB22729-1 & -54.34 & -37.81 & GC & Very fine sandy very coarse silt, coral fragments \\
\hline GeoB22730-1 & -54.87 & -37.69 & GS & Very coarse silty medium sand \\
\hline GeoB22731-1 & -54.77 & -37.64 & GS & Coarse silty fine sand, coral fragments \\
\hline GeoB22732-1 & -54.62 & -37.54 & GS & Coarse silty medium sand \\
\hline GeoB22733-1 & -54.60 & -37.50 & GS & Fine sandy coarse silt, coral fragments \\
\hline GeoB22738-1 & -53.97 & -37.33 & GS & Very fine sandy very coarse silt \\
\hline GeoB22739-2 & -54.38 & -38.59 & MeBo & Coarse silty fine sand \\
\hline GeoB22740-1 & -54.34 & -38.61 & GC & Very coarse silty very fine sand \\
\hline GeoB22741-1 & -54.31 & -38.64 & GC & Very coarse silty fine sand \\
\hline GeoB22744-2 & -54.54 & -38.30 & GBC & Very coarse silty very fine sand, coral fragments \\
\hline
\end{tabular}



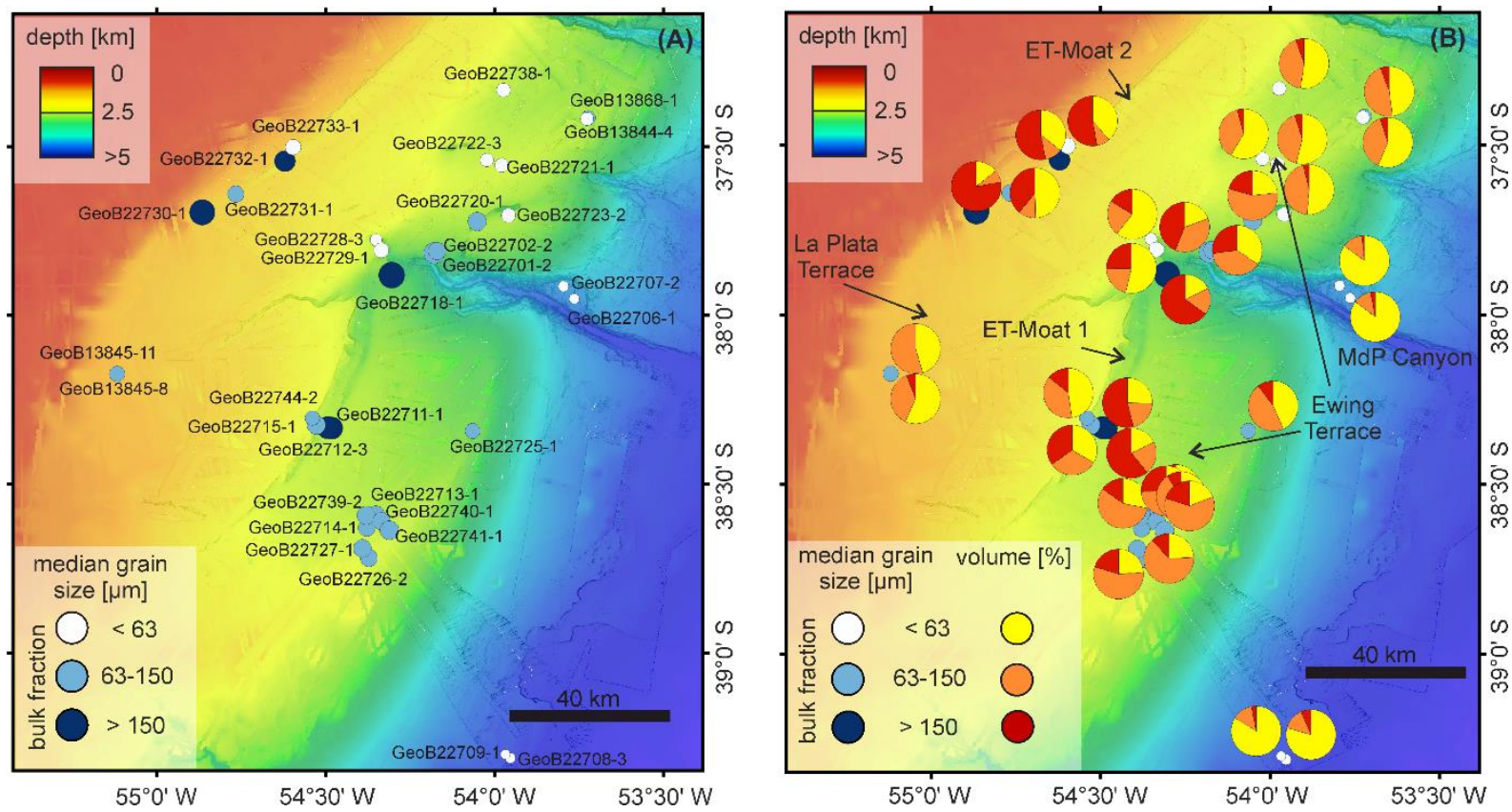

Fig. S2: (A) Median grain size of all the bulk sediment samples (<2000 $\mu \mathrm{m})$ analysed in this study and their names. (B) Pie chart showing the volume of sediments in three grainsize intervals of the mud and sand fraction. 